\title{
Surto de Circovirose (Síndrome Definhante Multissistêmica de Suínos Desmamados) no estado do Rio de Janeiro ${ }^{1}$
}

\author{
Ticiana do Nascimento França ${ }^{2}$, Paulo Vargas Peixoto ${ }^{3}$, Marilene Farias Brito ${ }^{4}$, \\ Nelson Morés ${ }^{5}$, Janice Zanella ${ }^{5}$ e David Driemeier ${ }^{6}$
}

\begin{abstract}
França T.N., Peixoto P.V., Brito M.F, Driemeier D., Mores N. \& Zanella J. 2005. [Outbreak of Circovirosis (Porcine Postweaning Multisystemic Wasting Syndrome) in the state of Rio de Janeiro, Brazil.] Surto de Circovirose (Síndrome Definhante Multissistêmica de Súnos Desmamados) no estado do Rio de Janeiro. Pesquisa Veterinária Brasileira 25(1):39-53. Universidade Estácio de Sá, Curso de Medicina Veterinária, Disciplina de Anatomia Patológica, Estrada Boca do Mato 850, Vargem Pequena, RJ 22783-320, Brazil. E-mail: ticianaf@uol.com.br

The first outbreak of Postweaning Multisystemic Wasting Syndrome (PMWS) in swine, which occurred in southeastern Brazil, in the state of Rio de Janeiro, is described. The disease, which affects mainly weaned about 4 month-old pigs, caused the death of at least 14 animals. The property, where the outbreak occurred, had inadequate sanitary and management conditions. Clinically the disease was characterized by wasting, poor development, cough, tachypnoea, dispnoea, diarrhoea, ataxia, tremors after stimulation, decubitus and convulsions. The course of the disease was acute or subacute. The most important post-mortem findings were enlarged lymphnodes, non-collapsed lungs, with consolidated areas mainly in the cranial lobes. Histological lesions consisted mainly of lymphohistiocytic infiltration with multinucleate giant cells in lymph nodes, spleen, Peyer's patches, kidney, lung and liver, depletion or lymphoid hyperplasia, as well as lymphohistiocytic interstitial pneumonia and areas of secondary bronchopneumonia. The diagnosis was established through observations of the symptoms and typical lesions, and was confirmed by immunohistochemical examination and PCR. The objective of this study was to characterize the epidemiological, clinical and pathological aspects of the outbreak of PMWS, because of the severe direct or indirect economical losses caused by the disease to the world pig industry.
\end{abstract}

INDEX TERMS: Postweaning multisystemic wasting syndrome, porcine circovirus type 2, pathology, immunohistochemistry, PCR.

${ }^{1}$ Recebido em 10 de agosto de 2004.

Aceito para publicação em 24 de setembro de 2004 .

Parte da Tese de Doutorado do primeiro autor, apresentada ao Curso de Ciências Veterinárias da Universidade Federal Rural do Rio de Janeiro (UFRRJ), em 8 de julho de 2004 .

${ }^{2}$ Disciplina de Anatomia Patológica, Curso de Medicina Veterinária da Universidade de Estácio de Sá (UNESA), Estrada Boca do Mato 850, Vargem Pequena, Rio de Janeiro, RJ 22783-320. *Autor para correspondência. Email: ticianaf@uol.com.br

${ }^{3}$ Depto Nutrição Animal e Pastagem, Instituto de Zootecnia, UFRRJ, Seropédica, RJ 23851-970.

${ }^{4}$ Depto Epidemiologia e Saúde Pública, Instituto de Veterinária, UFRRJ.

${ }^{5}$ Laboratório de Sanidade, Embrapa Suínos e Aves, Concórdia, SC 89700000 .

${ }^{6}$ Depto Patologia Clínica Veterinária, Faculdade de. Veterinária, UFRGS, Cx. Postal 15094, Porto Alegre, RS 91540-000.
RESUMO.- Descreve-se o primeiro surto de Síndrome Definhante Multissistêmica de Sú́nos Desmamados (SDMSD) na Região Sudeste do Brasil, no estado do Rio de Janeiro. A enfermidade que afetou principalmente suínos desmamados com idade em torno de 4 meses, levou a morte pelo menos 14 animais. A granja onde o surto ocorreu, tinha péssimas condições sanitárias e de manejo. Clinicamente, a doença caracterizou-se por má condição corporal, pouco desenvolvimento, tosse, taquipnéia, dispnéia, diarréia, ataxia, tremores após estímulo, decúbito e convulsões, com evolução aguda a subaguda. À necropsia, os achados mais importantes foram um aumento de volume de linfonodos e pulmões não-colapsados, com áreas consolidadas, principalmente nos lobos craniais e porção anterior dos lobos médios. $O$ exame histológico revelou, com maior freqüência, infiltração linfohistiocítica com células sinciciais em linfonodos, baço, placas de 
Peyer, rim, pulmão e fígado, depleção ou hiperplasia linfóide, bem como pneumonia bronco-intersticial linfo-histiocitária e áreas de broncopneumonia secundária. O diagnóstico firmouse pela observação dos sintomas e das lesões histológicas típicas e foi confirmado por exame imunohistoquímico e PCR. O estudo teve por objetivo caracterizar os aspectos epidemiológico e clínico-patológico desse surto, já que a mesma tem causado grandes perdas econômicas, diretas ou indiretas, à suinocultura mundial.

TERMOS DE INDEXAÇÃO: Síndrome Definhante Multissistêmica de Suínos Desmamados, circovírus porcino tipo 2, patologia, imunohistoquímica, PCR.

\section{INTRODUÇÃO}

A Síndrome Definhante Multissistêmica de Suínos Desmamados (SDMSD) foi descrita pela primeira vez no Canadá (Clark 1997), sendo posteriormente identificada em muitos outros países da América do Norte e do Sul, Europa e Ásia (Harding 1997, Allan et al. 1998, Ellis et al. 1998, Meehan et al. 1998, Morozov et al. 1998, Trujano et al. 2001, Choi et al. 2002, Sarradel et al. 2002). No Brasil, em 2000, a enfermidade ocorreu na Região Sul (Zanella \& Morés 2003) e, em 2002, na Região Sudeste (França 2004). Essa doença é causada por um pequeno vírus DNA, icosahédrico, não-envelopado, identificado por Tischer et al. (1974, 1982), como um contaminante de linhagem de células renais de suínos, sendo posteriormente agrupado, pelo Comitê Internacional de Taxonomia Viral, em uma nova família de vírus DNA, denominada Circoviridae (Luckert et al. 1995). Duas síndromes têm sido associadas mais freqüientemente a esse vírus: o tremor congênito suíno (TCS), afetando animais recém-nascidos, e uma nova doença denominada síndrome definhante multissistêmica de suínos desmamados. A natureza infecciosa da primeira tem sido reconhecida há alguns anos, entretanto a SDMSD parece ser uma doença emergente em suínos (Lukert \& Allan 1999). A infecção por circovírus já foi verificada também em frangos (anemia viral em frangos), psitacídeos (doença viral do bico e da pena), pombos (Kiupel et al. 1998) e, até mesmo, em pacientes humanos dialíticos; recentemente, o circovírus foi verificado em humanos na França (Gallian et al. 2002). O circovírus causa TCS, quando porcas prenhes são expostas ao vírus, em diferentes fases da gestação, caracterizando-se clinicamente a infecção por tremores bilaterais, afetando a musculatura esquelética (Lukert \&Allan 1999).

Animais afetados pela SDMSD têm entre 8 e 16 semanas de idade (Allan \& Ellis 2000) e apresentam perda de peso, emaciação, taquipnéia, dispnéia e, menos comumente, diarréia, tosse e distúrbios nervosos, emagrecimento, dispnéia, aumento de linfonodos, e, por vezes, diarréia e icterícia (Larochelle et al. 2003).

A SDMSD tem sido associada ao PCV-2 (circovírus porcino tipo 2), um vírus antigenicamente e geneticamente diferente de PCV-1, considerado não-patogênico (Allan et al. 1998, Morozov et al. 1998). Enquanto a SDMSD é esporádica, a infecção por PCV-2 é comum e está presente na população suína desde 1985 no Canadá e Bélgica e desde 1973, na Irlanda (Magar et al. 2000). Embora geralmente lesões leve a moderadas tenham sido reproduzidas experimentalmente em suínos jovens por inoculação do PCV-2 (Allan et al. 1999, Magar et al. 2000), doença severa tem sido demonstrada principalmente após a coinfecção com parvovírus porcino - PPV (Allan et al. 1999, Kennedy et al. 2000, Krakowka et al. 2000) e pelo vírus da síndrome respiratória e reprodutiva porcina - PRRSV (Allan et al. 2000, Rovira et al. 2002), bem como após imuno-estimulação por vacinas e drogas imunomoduladoras (Krakowka et al. 2001, Kyriakis et al. 2002).

De qualquer forma, co-circulação e coinfecção também foram observadas em propriedades sem SDMSD e animais com SDMSD podem ser negativos para PPV e PRRSV (Larochele et al. 2003). A ocorrência de SDMSD nas propriedades não pode ser associada apenas à coinfecção com PRRSV ou PPV ou ao uso de imunoestimulantes, como vacinas, ou a diferenças genômicas entre as cepas de PCV-2 identificadas. Estudos adicionais serão necessários para o melhor entendimento dos fatores de risco associados com SDMSD e seus mecanismos desencadeantes (Larochele et al. 2003). Verificou-se ainda que em propriedade com ou sem SDMSD, foram detectados baixos níveis de anticorpos em animais com 3 semanas de idade, fato provavelmente associado à imunidade passiva. Nesses animais, os níveis de anticorpos gradualmente descrescem, ficando muito baixos ou ausentes por volta de 11 semanas.

A morbidade e a mortalidade em suínos desmamados mostram-se superiores a 50\% em algumas criações (Harding 1997); pode ser observada alta mortalidade em suínos com sintomas, porém a morbidade geralmente é baixa (Lukert \& Allan 1999).

Na necropsia observam-se vários graus de emagrecimento corporal. A pele está pálida e ictérica em $20 \%$ dos casos, os linfonodos estão aumentados de volume (3-4 vezes) e homogeneamente brancos na superfície de corte. Os pulmões apresentam-se armados (não-colapsados), firmes ou “emborrachados", com superfície mosqueada por lóbulos marrom-acinzentados, entremeados por lóbulos amarelados a róseos. Grandes áreas atelectáticas ou consolidadas são comuns nos lobos intermediário e cranial. O fígado pode ser macroscopicamente normal na metade dos animais ou mosqueado, com lóbulos menores, mais proeminentes e aumento do tecido conectivo interlobular no restante dos casos. $\mathrm{O}$ baço geralmente está aumentado de volume, não-congesto e carnoso (pulposo) na superfície de corte. Focos brancos subcapsulares podem ser evidenciados nos rins, assim como palidez e aumento de volume em função do edema (Luckert \& Allan 1999). A lesão microscópica comum, infiltração linfohistiocitária, com presença de células gigantes e, por vezes, inclusões virais no citoplasma de macrófagos, pode ser encontrada no pulmão, rim, fígado, pâncreas e tecidos linfóides (Kiupel et al. 1998). Perivasculite granulomatosa segmentar foi verificada na cápsula de linfonodos, membranas serosas, tecidos perioculares, leptomeninges e derme superficial (Kiupel et al. 1998). Órgãos e tecidos linfóides podem mostrar perda de linfócitos B e expansão de células T em seus folículos (Lukert \& Allan 1999), porém os achados mais específicos são depleção linfocítica, infiltração histiocítica com células gigantes e inclusões víricas intra-citoplasmáticas nestas últimas células (Clark 1997). 
O presente trabalho teve como objetivo a caracterização epidemiológica e clínico-patológica, confirmada por exames imunohistoquímicos e PCR, de um surto de Síndrome Definhante Multissistêmica de Suínos Desmamados (SDMSD) no Estado do Rio de Janeiro.

\section{MATERIAL E MÉTODOS}

Animais. Os estudos foram realizados em 5 suínos, mestiços (Landrace $\mathrm{x}$ Large White), com aproximadamente 4 meses de idade, de ambos os sexos, advindos de uma pequena criação de Ilha de Guaratiba, Município do Rio de Janeiro, RJ. Os animais deram entrada em datas diferentes e, alguns deles, permaneceram isolados, por até 2 meses, em nossas dependências.

Visitas à propriedade. Em 8.4.2002 foi realizada uma visita à propriedade em Ilha de Guaratiba, Rio de Janeiro, para colheita de histórico. Após várias tentativas de contato por telefone, sem sucesso, foi realizada uma segunda visita, em 27.6.2004, na qual se observou que a granja havia sido desativada. Em 7.7.2004, após contato por telefone, o proprietário informou que o sítio havia sido vendido entre maio e junho de 2002.

Instalações. Os exames clínicos e a necropsia foram realizados nas dependências do Setor de Anatomia Patológica, Convênio "Projeto Sanidade Animal Embrapa/UFRRJ”, Km 47, Seropédica, RJ. Os animais eram mantidos isolados em baias individuais de alvenaria, com piso de cimento, medindo $2 \times 2 \mathrm{~m}$, cada qual com seu bebedouro e comedouro; constituiu exceção o Suíno 1, enviado morto.

Alimentação. Os quatro animais foram alimentados com ração comercial, duas vezes ao dia e água à vontade.

Exames clínicos. Durante o período em que os animais foram mantidos isolados para estudos, realizaram-se exames clínicos diários que incluíam observação das frequiências cardíaca e respiratória, verificação da temperatura retal, avaliação das mucosas, fezes e urina, palpação de fígado, baço e linfonodos e auscultações cardíaca e respiratória. Adicionalmente, em 16.4.2004, foram coletadas amostras de sangue (20 ml), por punção da jugular dos Suínos 2, 4 e 5.

Necropsias. Os suínos foram necropsiados imediatamente após morte ou sacrifício (Quadro 1), com exceção do Suíno 4 que morreu de madrugada e foi necropsiado pela manhã. Todos os órgãos foram avaliados e fragmentos de fígado, rins, baço, pâncreas, adrenal, bexiga, intestinos delgado e grosso, estômago, pulmões, coração, encéfalo, tireóide, músculo estriado, hipófise e pele foram colhidos e fixados em formalina a $15 \%$, para exames histológicos; o formol foi trocado $8 \mathrm{~h}$ após a primeira fixação e novamente depois de 24 horas.

\section{Quadro 1. Suínos necropsiados}

\begin{tabular}{lccccl}
\hline Animal & $\begin{array}{c}\text { Idade / } \\
\text { chegada }\end{array}$ & Sexo & $\begin{array}{c}\text { Data de } \\
\text { chegada }\end{array}$ & Necropsia & \\
\hline Suíno 1 & \pm 4 meses & F & 26.02 .02 & 26.02 .02 & Morte natural \\
Suíno 2 & \pm 4 meses & F & 26.02 .02 & 26.04 .02 & Animal sacrificado \\
Suíno 3 & \pm 4 meses & F & 15.04 .02 & 15.04 .02 & Animal sacrificado \\
Suíno 4 & \pm 4 meses & M & 15.04 .02 & 20.04 .02 & Morte natural \\
Suíno 5 & \pm 4 meses & M & 15.04 .02 & 10.06 .02 & Animal sacrificado
\end{tabular}

Histopatologia. Após a fixação em formalina, os fragmentos de órgãos dos suínos foram desidratados em álcool absoluto, tratados com xilol e depois embebidos e incluídos em parafina, cortados a 5 micrômetros de espessura e corados pela Hematoxilina e Eosina (HE), para serem analisados posteriormente. Outras colorações especiais também foram utilizadas (Ziehl Neelsen e Ácido Periódico de Schiff) em cópias das lâminas não-coradas pela HE.
Exames imunohistoquímico e PCR. Amostras de linfonodos e pulmões (material emblocado em parafina e cortes histológicos sem corantes), de todos os suínos, foram enviados para realização de PCR no Setor de Patologia da Embrapa Suínos e Aves, Concórdia, SC, e de exame imunohistoquímico, pelo Setor de Patologia Animal da Universidade Federal do Rio Grande do Sul (URFGS).

\section{RESULTADOS}

Aspectos epidemiológicos. Os suínos estudados faziam parte de um plantel constituído por 50 leitões de 4 meses, 20 de dois meses, 13 porcas adultas e dois cachaços. Aos 30 dias após o parto, as porcas e os leitões eram agrupados com outras porcas paridas. O desmame na propriedade era realizado aos 3 meses de idade, depois do qual os leitões eram colocados, todos juntos, em uma "pocilga" de 10x20 m, permancendo neste local até os 9 meses de idade, sendo após esse período, encaminhados ao abate com cerca de $100 \mathrm{~kg}$. Os animais eram vermifugados aos 30 e aos 100 dias de idade. Foram utilizados antibióticos à base de penicilina e

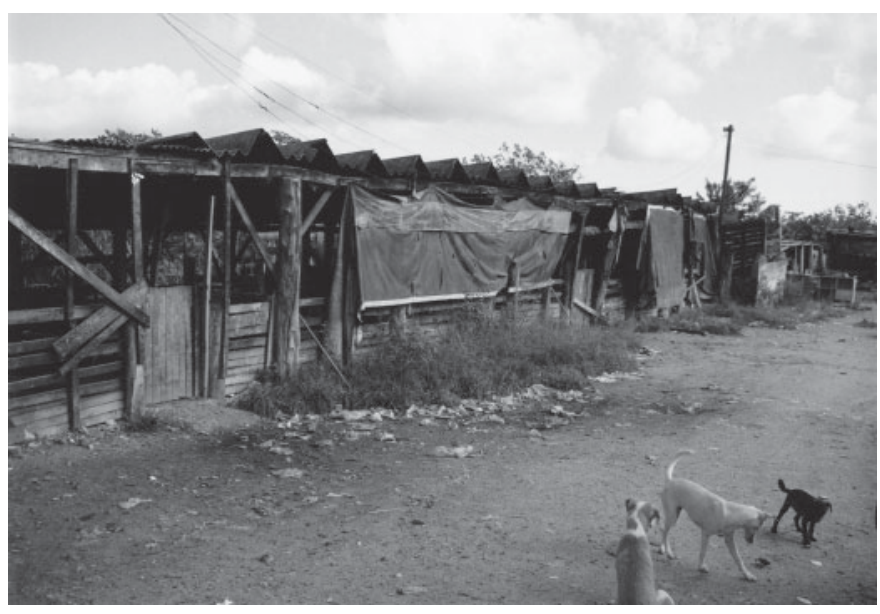

Fig.1. Surto de Circovirose (SDMSD) no Estado do Rio de Janeiro. Extrema precariedade das instalações na propriedade onde ocorreu o surto. Outros animais eram criados juntos com os suínos. Ilha de Guaratiba, Rio de Janeiro.

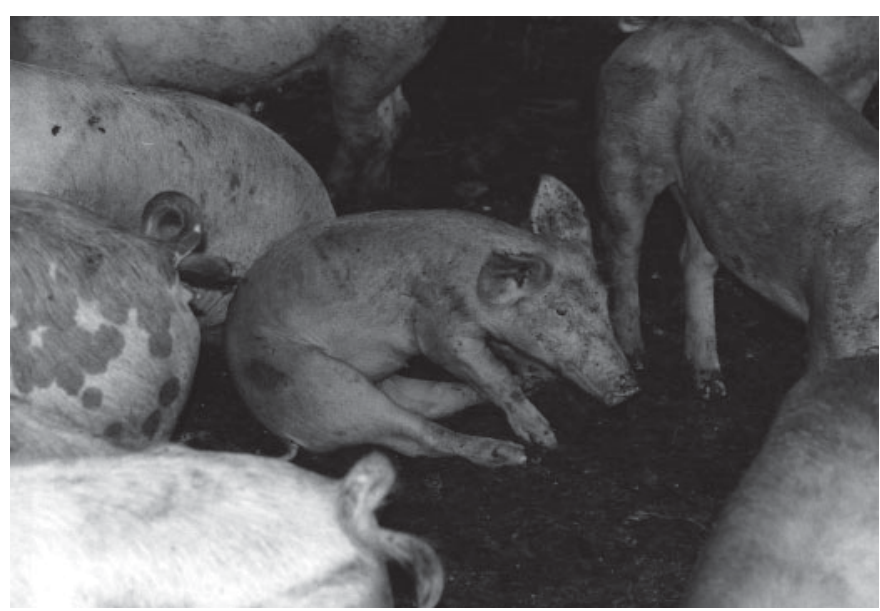

Fig. 2. Suíno em posição ortopnéica, apático e magro, no surto de Circovirose (SDMSD) em Ilha de Guaratiba, Rio de Janeiro. 
diidroestreptomicina em alguns animais doentes, os quais não apresentaram qualquer melhora. Os animais não eram vacinados. Em visita à propriedade, em 8.4.02, verificou-se que as instalações reservadas a todas as categorias de suínos eram de extrema precariedade (Fig.1), constituída de retalhos de lata, papelão, madeira e demais materiais de sucata. A alimentação dos mesmos constituíase de resíduos recolhidos de vários restaurantes, misturados ao lixo (sacos, copos e pratos plásticos, garrafas, latas, cascas de laranja, abacaxi e de outras frutas, dentre outras sujidades típicas de alimentos descartados); o "alimento" era atirado ao solo para que os animais o selecionassem e ingerissem. Atrás dessas instalações havia uma "vala de dejetos" e uma lixeira para vidros, garrafas e latas. Cães, gatos e urubus também tinham contato com os suínos.

Segundo informação do proprietário (8.4.02), essa criação suína existia há pelo menos 10 anos (à época pertencia a outro proprietário). Novos animais, oriundos de São Paulo (Itaocara) e do Paraná, foram introduzidos no plantel, entre outubro e novembro de 2001. Os primeiros casos da doença apareceram em novembro de 2001. Quatorze leitões morreram até abril de 2004 (16,5\% de mortalidade); nenhum animal que adoeceu se recuperou. O proprietário relatou nunca ter visto essa doença anteriormente e também que nenhuma criação suína vizinha teria apresentado essa enfermidade. Os animais com idade entre 2 e 4 meses seriam mais freqüientemente afetados e os que apresentavam peso acima de $40 \mathrm{~kg}$ não morreriam.

Em recente visita à propriedade (27.6.04), verificamos que a criação foi desativada. Conseguimos novo contato com o proprietário apenas em 7.7.04; fomos informados que praticamente todos os leitões entre 2 e 4 meses de idade morreram ou apresentaram emagrecimento e apatia, impossibilitando a manutenção da criação. O proprietário não soube informar, com precisão, quantos animais foram sacrificados. A criação foi desativada entre maio e junho de 2002 e o sítio foi vendido.

Quadro clínico verificado durante a visita. Entre os animais em fase de crescimento, havia vários animais magros e pouco desenvolvidos, parte dos quais com tosse. Outros tinham condição corporal próxima da normal, porém também tossiam. Verificaram-se ainda um animal macho com tendência ao decúbito esternal e sonolência; outro em posição ortopnéica, taquipnéico e bem magro (Fig.2). Além da tosse, um outro suíno apresentou diarréia em jatos, de cor cinza-chumbo; uma fêmea, com cerca de 4 meses de idade, evidenciou moderada dispnéia, emagrecimento e respiração predominantemente abdominal. A enfermidade, na maioria das vezes, apresentou evolução aguda à subaguda, entretanto alguns animais que evidenciaram sintomas como emagrecimento e tosse, provavelmente, tiveram evolução crônica, mas não apresentaram quadro clínico grave e não foram liberados pelo proprietário para estudo. $O$ responsável pelo plantel informou, durante essa visita, que alguns suínos apresentavam diarréia amarela a enegrecida, tremores após estímulo e ataxia depois de sofrer crise convulsiva, bem como hipertermia e polidipsia, em animais que ficavam cianóticos após a morte. Ainda segundo o proprietário os suínos com apatia desenvolviam doença com evolução de 1 a 2 dias, já os que apresentavam convulsões, tinham evolução de até 5 dias; em parte dos animais, a evolução chegou a 10 dias. Uma vez que os animais entravam em decúbito, não mais se levantavam.
Quadro clínico verificado nos animais enviados para estudo. Suíno 1. Animal chegou morto. - Suíno 2. Estado nutricional regular/ruim, episódios de diarréia e moderada palidez em mucosas. Após um mês, o animal se recuperou, porém continuou com desenvolvimento abaixo do esperado para sua idade. Posteriormente, o animal apresentou moderada congestão em mucosas conjuntivais e episódio de diarréia com coloração marrom-acinzentada. Durante o estudo, o suíno apresentou apetite normal. Animal sacrificado em 26.4.02. - Suíno 3: Estado nutricional regular/ruim, dispnéia e ruído expiratórios, respiração predominantemente abdominal, expiração forçada e estertorosa. À auscultação, o campo pulmonar esquerdo apresentava estertores e sibilos discretos. Animal freqüientemente em decúbito. Em adição, verificou-se discreta hipertermia ocasional, mucosas conjuntivais moderadamente congestas e sensibilidade cutânea um pouco diminuída no tronco. Animal sacrificado "in extremis" em 15.4.02. - Suíno 4. Estado nutricional regular/ruim, respiração audível, acentuada dispnéia predominantemente expiratória, mesmo em repouso, tosse produtiva, apetite diminuído e linfonodos inguinais superficiais um pouco aumentados de volume. Animal apático, em decúbito lateral frequiente, não se levantava após estímulo, expiração forçada, estertores úmidos na região ventral do campo pulmonar direito, com aumento dos ruídos tráqueo-brônquico e bronco-bronquiolar; no campo pulmonar esquerdo verificou-se aumento dos ruídos tráqueo-brônquico e bronco-bronquiolar com crepitação precoce na expiração. Mucosa conjuntival muito congesta, pálpebras aderidas e com crostas amarronzadas (conjuntivite). Animal apresentou evolução de pelo menos 5 dias (suíno encontrado morto em 20.4.02). - Suíno 5. Estado nutricional regular/ruim, com freqüência em posição de cão sentado, expiração entrecortada com ruído no final, acentuada dispnéia expiratória, ruído tráqueo-brônquico mais aumentado no campo pulmonar esquerdo. Campo pulmonar direito com dispnéia expiratória, sibilos e crepitações, no final da inspiração. Mucosa conjuntival moderadamente congesta, com secreção purulenta no olho esquerdo (pálpebras "coladas"). Adicionalmente foram verificados movimentos respiratórios com pequena amplitude e, em algumas dias, perda de apetite. Segundo informação de um funcionário responsável pela limpeza, havia claudicação esporádica. Animal sacrificado em 10.6.02.

Resultados dos exames de sangue. Suíno 2. Segmentados: $24 \%$ (28-47\%), linfócitos: 67\% (25-60\%), anisocitose discreta, policromasia discreta, neutropenia (relativa), linfocitose (relativa), leucometria global baixa para idade do animal. Proteínas séricas totais: $6,48 \mathrm{~g} / \mathrm{dL}(7,9-8,9 \mathrm{~g} / \mathrm{dL})$, albumina: $3,75 \mathrm{~g} / \mathrm{dL}(1,8-$ $, 3,3 \mathrm{~g} / \mathrm{dL})$, globulinas $2,73 \mathrm{~g} / \mathrm{dL}(5,29-6,43 \mathrm{~g} / \mathrm{dL})$, relação albumina/ globulina: $1,37(0,37-0,51)$, fosfatase alcalina: 55,2U/L $(9,0-31 \mathrm{U} /$ L) e TGP: $46,5 \mathrm{U} / \mathrm{L}(9,0-17 \mathrm{U} / \mathrm{L})$, bilirrubina indireta: $0,63 \mathrm{mg} / \mathrm{dL}(0,0-$ 0,3mg/dL), fibrinogênio: $600 \mathrm{mg} / \mathrm{dL}$ (100-500mg/dL). - Suíno 4. Presença de macroplaquetas, anisocitose discreta, policromasia discreta, leucometria total baixa para idade do animal. Relação algumina/globulina: $0,66(0,37-0,51)$, bilirrubina indireta: $0,76 \mathrm{mg} /$ $\mathrm{dL}(0,0-0,3 \mathrm{mg} / \mathrm{dL})$, proteínas plasmáticas: $9,40 \mathrm{~g} / \mathrm{dL}(6,0-8,0 \mathrm{~g} / \mathrm{dL})$ e fibrinogênio: $600 \mathrm{mg} / \mathrm{dL}$ (100-500mg/dL). - Suíno 5. Anisocitose discreta, policromasia discreta, presença de macroplaquetas, desvio nuclear de neutrófilos à esquerda discreto (relativo), 
leucometria total baixa para idade do animal. Proteínas séricas totais: $6,35 \mathrm{~g} / \mathrm{dL}(7,9-8,9 \mathrm{~g} / \mathrm{dL})$, globulinas: $3,45 \mathrm{~g} / \mathrm{dL}(5,29-6,43 \mathrm{~g} /$ $\mathrm{dL})$, relação albumina globulina: $0,84(0,37-0,51)$, bilirrubina indireta: $0,68 \mathrm{mg} / \mathrm{dL}(0,0-0,3)$.

Achados de necropsia. Suíno 1. Animal enviado morto e necropsiado em 26.2.02. Estado nutricional regular/ruim, carcaça um pouco amarelada, com equimoses na região ventral (cervical, torácica, axilar, abdominal e inguinal). Mucosas moderadamente pálidas. Fezes ressecadas, cinza-amarronzadas, aderidas ao redor do ânus. Linfonodos superficiais com moderado aumento de volume. Cavidade torácica com pequena quantidade de líquido límpido um pouco amarelado. Os pulmões apresentavam-se marmorizados e com presença de muco na tranquéia. Cavidade abdominal com pequena quantidade de líquido avermelhado e coágulos aderidos ao omento maior. Fígado moderadamente congesto. Baço levemente aumentado de volume e com leve congestão. Os rins apresentavam a região cortical pálida e as papilas moderadamente avermelhadas. Havia moderada congestão na região fúndica do estômago; pequena quantidade de conteúdo líquido. Os linfonodos mesentéricos apresentavam-se moderadamente aumentados de volume; vasos sangüíneos mesentéricos marcadamente congestos. As fezes estavam amareladas e espumosas no intestino delgado e acinzentadas e com presença de terra no ceco. Adicionalmente verificou-se marcada congestão dos vasos da meninge no sistema nervoso central. - Suíno 2. Sacri- ficado e necropsiado em 26.4.02. Estado nutricional regular/ruim. Verificou-se leve hidropericárdio (10-15ml), coração com moderada hipertrofia bilateral ventricular, mais marcada no ventrículo esquerdo e presença de aderências fibrosas entre a pleura visceral (lobo cranial direito) e a pleura parietal (região anterior do tórax), com atrofia deste lobo; abaixo dessas aderências havia áreas de consolidação do parênquima, com coloração bege-acinzentada. Suíno 3. Animal morreu e foi necropsiado em 15.4.02. Estado nutricional regular/ruim, cornetos levemente avermelhados, linfonodos superficiais moderadamente e tireóide $(2,0 \times 1,5 \mathrm{~cm})$ levemente aumentados de volume. Cavidade torácica com aderências entre as pleuras parietal e visceral, que se desfaziam facilmente. Timo hipotrófico (atrófico). Linfonodos tráqueobrônquicos e cervicais com acentuado aumento de volume, um deles medindo $3 \times 2 \mathrm{~cm}$, com superfície de corte levemente protraída e apresentando pequenos pontos avermelhados subcapsulares que se projetavam para as áreas paracorticais até a medula e hilo. Os pulmões encontravam-se muito pesados, com grandes áreas de consolidação, bilaterais, de coloração bege-acinzentada ou róseo-acinzentada e mais deprimidas, visíveis principalmente nos lobos craniais, médios e acessório (Fig. 3). Nos lobos caudais observaram-se também áreas de consolidação, em meio a parênquima normal ou mais elevado (enfisema compensatório). Havia plasma coagulado e levemente turvo sob a pleura. Verificou-se ainda marcada hipertrofia concêntrica bilateral, com leve dilatação do
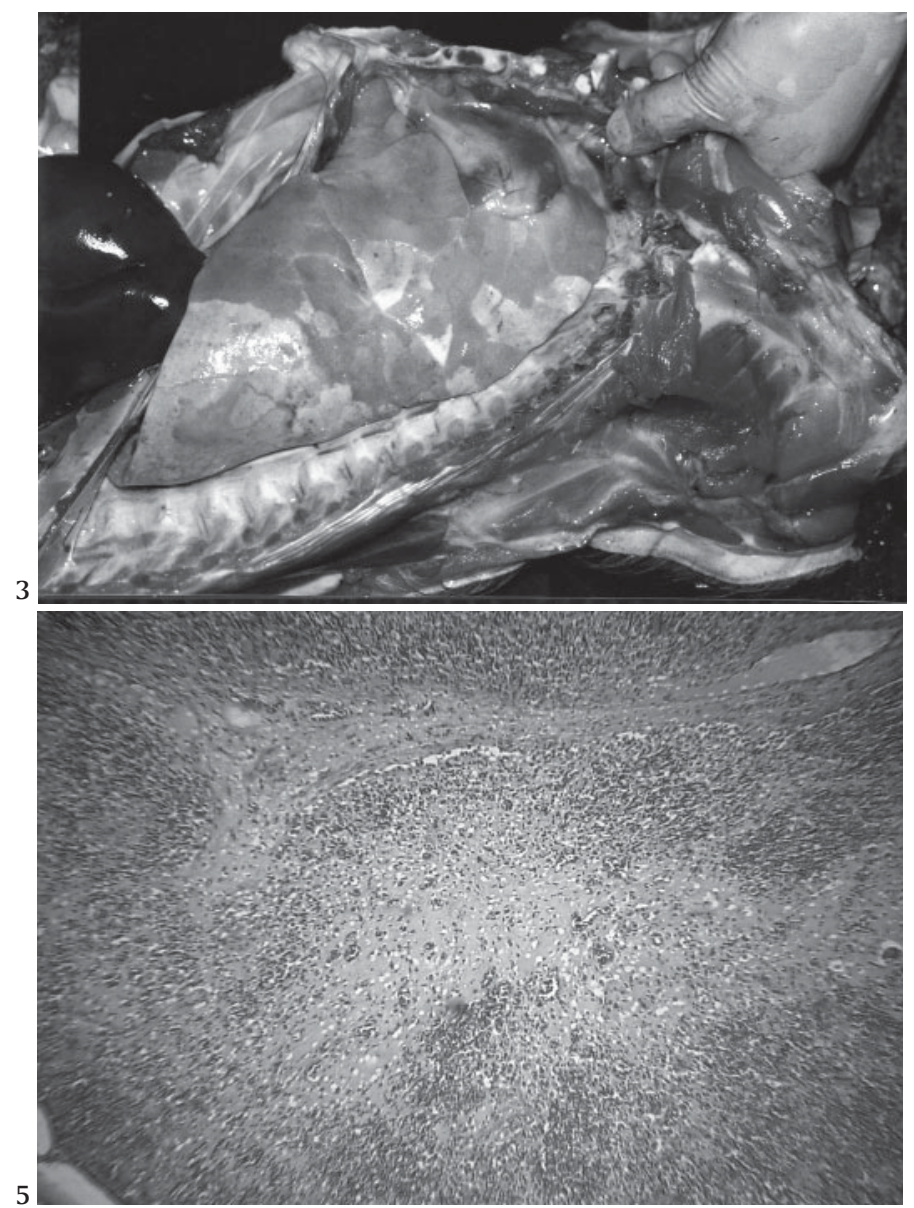

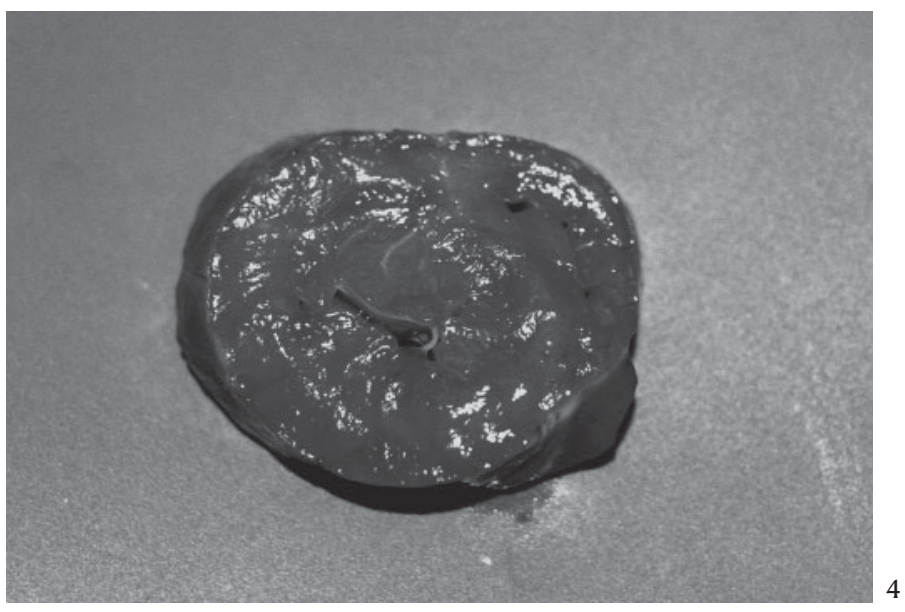

Fig. 3. Pulmão esquerdo não-colapsado, com áreas consolidadas, róseoacinzentadas ou bege-acinzentadas, afetando os lobos cranial, médio e parte do lobo caudal (Suíno 3), no surto de Circovirose (SDMSD) no estado do Rio de Janeiro.

Fig. 4. Corte transversal do coração evidenciando marcada hipertrofia da musculatura dos ventrículos, principalmente do esquerdo (Suíno 3), no surto de Circovirose (SDMSD) no estado do Rio de Janeiro.

Fig. 5. Linfonodo com marcada depleção linfóide e exsudato inflamatório misto (Suíno 1), no surto de Circoviose (SDMSD) no estado do Rio de Janeiro. HE, obj. 4. 

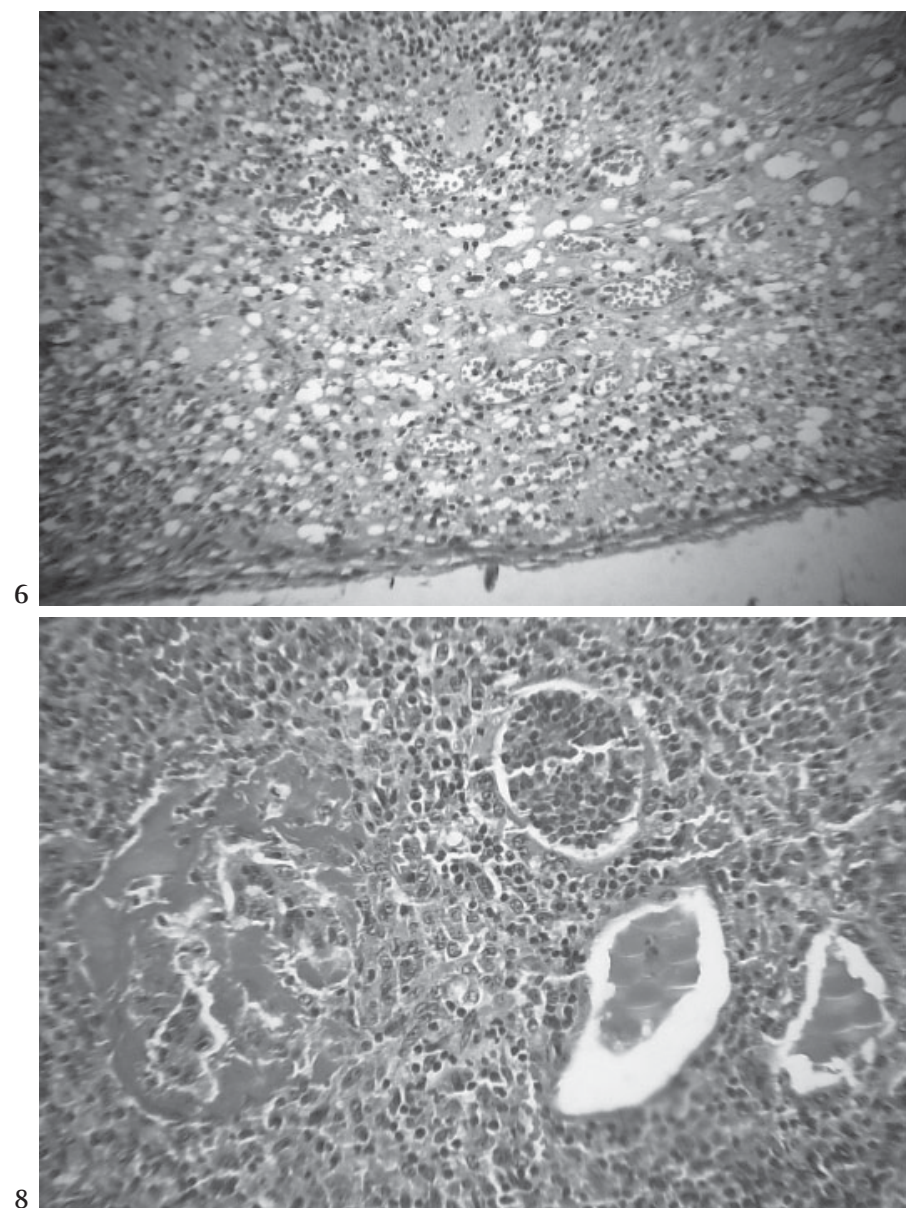

Fig. 6. Linfonodo com marcada depleção linfóide e exsudato inflamatório misto no seio subcapsular (Suíno 1), no surto de Circovirose (SDMSD) no estado do Rio de Janeiro. HE, obj. 16x.

Fig. 8. Destruição do glomérulo pelo excesso de filtrado (seta); cilindros hialinos e detritos celulares em túbulos; leve infiltração inflamatória predominantemente linfo-histiocítica no intestício (Suíno 1), no surto de Circovirose (SDMSD) no estado do Rio de Janeiro. HE, obj. 16x.

coração direito e áreas levemente mais claras no miocárdio (Fig. 4). O figado estava pálido, levemente amarelado e com lobulação discretamente mais evidente em algumas regiões; vesícula biliar com conteúdo de aspecto gelatinoso. $O$ baço apresentava-se levemente aumentado, com cápsula um pouco tensa e superfície de corte granular, com folículos linfóides proeminentes. Linfonodos mesentéricos leve a moderadamente aumentados de volume e discretamente avermelhados no seio subcapsular. Ao corte, vários linfonodos, especialmente os tráqueo-brônquicos, apresentaram pequenos focos esbranquiçados de aproximadamente $0,2 \mathrm{~cm}$ de diâmetro (hiperplasia de folículos linfóides). A medula óssea encontrava-se bastante avermelhada e densa (mais ativa); tempo de coagulação diminuído (sangue coagulava rapidamente). Adicionalmente verificaram-se pequenas erosões na região fúndica estomacal. - Suíno 4. Animal morreu e foi necropsiado em 20.4.02 (suíno encontrado morto às 9:00 h). Estado nutricional regular/ ruim. Linfonodos ilíacos internos avermelhados na região cortical
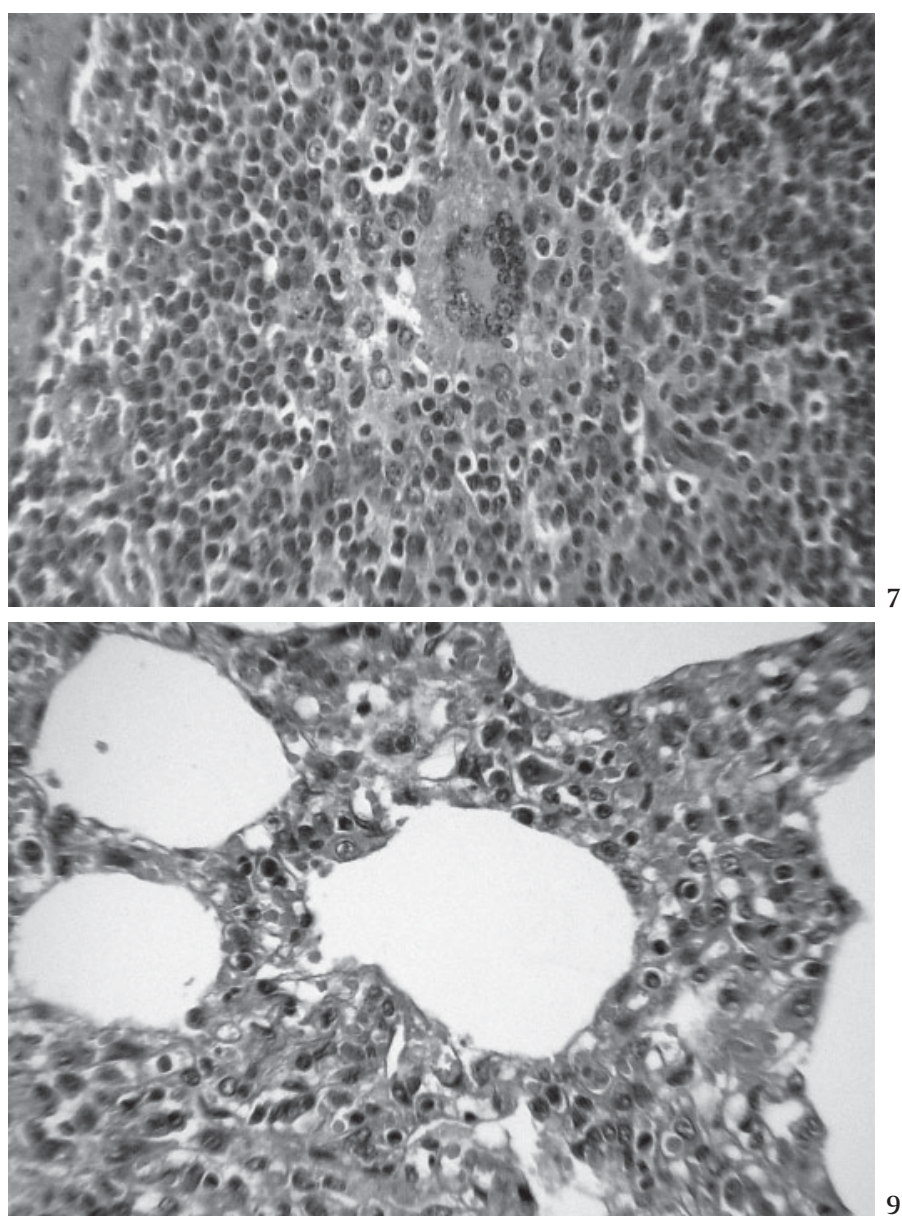

Fig. 7. Linfonodo com presença de célula sincicial e infiltração linfohistiocitica em folículo (Suíno 3), no surto de Circovirose (SDMSD) no estado do Rio de Janeiro. HE, obj. 25x.

Fig. 9. Pneumonia intersticial caracterizada por infiltração inflamatória predominantemente linfo-histiocítica, determinando marcado espessamento da parede alveolar (Suíno 1), no surto de Circovirose (SDMSD) no estado do Rio de Janeiro. HE, obj. 40x.

e levemente aumentados de volume. Lobos pulmonares, craniais e médios, com pequenas áreas levemente deprimidas e algo mais elásticas, de coloração róseo-acinzentada. Coração com leve hipertrofia concêntrica do ventrículo esquerdo. Na cavidade abdominal verificou-se avermelhamento e espessamento por edema do mesentério e linfonodos mesentéricos moderadamente aumentados de volume e avermelhados. A parede do intestino delgado e do intestino grosso apresentava-se intensamente avermelhada e edemaciada; o conteúdo intestinal era sanguinolento, com coágulos e pequenos flocos de fibrina. $\mathrm{O}$ fígado, em algumas áreas, tinha a lobulação mais evidente. - Suíno 5. Sacrificado e necropsiado em 10.6.02. Estado nutricional regular/ruim. Cavidade torácica com presença de $100 \mathrm{ml}$ de líquido discretamente amarelado. Pulmão apresentando aderência entre a pleura e o diafragma, com formação de um foco de fibrose na aderência. Havia consolidação dos lobos craniais e cardíacos (100\%) e de áreas dos lobos caudais, mais marcada na face ventral; $60 \%$ do pulmão estava consolidado; 
os lobos caudais apresentavam-se armados, enfisematosos, com coloração bege-acinzentada. Ao corte verificou-se que as paredes dos brônquios e bronquíolos estavam moderada a acentuadamente espessadas, além da presença de pequenos pontos esbranquiçados, ligeiramente elevados no parênquima. Os linfonodos mediastínicos encontravam-se moderadamente aumentados de volume (3 vezes) e com coloração avermelhada. Havia acentuada hipertrofia concêntrica do ventrículo esquerdo e moderada dilatação do ventrículo direito. Verificaram-se $50 \mathrm{ml}$ de líquido translúcido, levemente amarelado, na cavidade abdominal. Observaram-se distribuição irregular de sangue no fígado, região fúndica estomacal difusamente avermelhada e intestino delgado com moderada quantidade de conteúdo mucoso.

Achados histopatológicos. As lesões histológicas caracterizadas encontram-se pormenorizadas nos Quadros 2 a 6 e nas Figuras 5 a 9.

Colorações especiais. A coloração pelo PAS (para fungos) e pelo Ziehl-Neelsen (para bactérias álcool-ácido resistentes), re- alizadas em fragmentos de linfonodos e pulmões, dos 5 suínos, tiveram resultado negativo.

Exame imunohistoquímico e PCR. $\mathrm{O}$ exame imunohistoquímico evidenciou grande quantidade de antígenos de PCV-2 no fragmento de pulmão do Suíno 1; não havia antígenos do vírus detectáveis no linfonodo desse animal, nem em linfonodos e pulmões dos outros suínos. A técnica pelo PCR, revelou DNA de PCV-2 em tecido pulmonar do Suíno 1, porém foi negativa para a amostra de linfonodo desse mesmo animal e para os fragmentos de linfonodos e pulmões dos demais suínos, que permaneceram por mais de 6 meses em formalina.

\section{DISCUSSÃO}

O diagnóstico da Síndrome Definhante Multissistêmica de Suínos Desmamados (SDMSD) baseou-se nos achados epidemiológicos, clínicos e anátomo-patológicos e nas típicas alterações histopatológicas, confirmados pela demonstração através de

Quadro 2. Surto de Circovirose (Síndrome Definhante Multissistêmica de Suínos Desmamados) no estado do Rio de Janeiro. Achados histopatológicos nos linfonodos

\begin{tabular}{|c|c|c|c|c|c|c|c|}
\hline Animal & $\begin{array}{l}\text { Depleção } \\
\text { linfóide }\end{array}$ & $\begin{array}{l}\text { Necrose de } \\
\text { coagulação }\end{array}$ & Hiperplasia & $\begin{array}{l}\text { Infiltração } \\
\text { macrofágica }\end{array}$ & Exsudato & Fibrose & Observações \\
\hline Suíno 1 & $\begin{array}{l}\mathrm{F}^{\mathrm{a}}++^{\mathrm{b}} \mathrm{a}+++ \\
\mathrm{RPC}^{\mathrm{C}}++\mathrm{a}+++\end{array}$ & $\mathrm{F}+$ & - & $\begin{array}{l}\mathrm{F}+\mathrm{a}+++ \\
\mathrm{RPC}+\mathrm{a}+++ \\
\mathrm{SS}^{\mathrm{d}}+\mathrm{a}+++\mathrm{c} / \text { cé- } \\
\text { lulas sinciciais }++ \\
\text { hemácias }+ \text { e fibri- } \\
\text { na }+\mathrm{a}++ \text {, locali- } \\
\text { zados nos SS, RPC } \\
\text { e cápsula }\end{array}$ & $\begin{array}{l}\text { Macrófagos }+++, \\
\text { linfócitos }+ \text {, neu- } \\
\text { trófilos }++ \text {, célu- } \\
\text { las sinciciais }++\end{array}$ & $\begin{array}{l}\mathrm{SS}+\mathrm{a}++ \\
\mathrm{RPC}+\mathrm{a}++ \\
\text { Cápsula }++\end{array}$ & $\begin{array}{l}\text { Moderada infiltração neutrofílica em um } \\
\text { dos linfonodos. } \\
\text { Inclusões víricas intracitoplasmáticas } \\
\text { anfofílicas em macrófagos. } \\
\text { Células sinciciais numerosas em região } \\
\text { para-cortical }\end{array}$ \\
\hline Suíno 2 & - & - & $\begin{array}{l}\mathrm{F}+(+) \text { com } \\
\text { mitoses nu- } \\
\text { merosas } \\
\mathrm{SS}+\mathrm{a}++ \\
\mathrm{RPC}+\mathrm{a}++\end{array}$ & $\begin{array}{l}\mathrm{SS}+\mathrm{a}++ \\
\mathrm{F}+ \\
\text { Medular }+ \\
\mathrm{RPC}+\mathrm{a}++\end{array}$ & SS (+) & $\begin{array}{l}\mathrm{SS}+ \\
\mathrm{RPC}+\mathrm{a}++\end{array}$ & $\begin{array}{l}29647 \text { A e } 29648 \text { F- microabscesso e des- } \\
\text { truição folicular }(+) \\
29648 \text { A - raras células sinciciais em re- } \\
\text { gião para-cortical }\end{array}$ \\
\hline Suíno 3 & $\begin{array}{l}\mathrm{F}+\mathrm{a}++, \\
\text { com cariorrexia }\end{array}$ & $\begin{array}{l}\mathrm{F}(+) \\
\mathrm{RPC}(+)\end{array}$ & $\begin{array}{l}\mathrm{F}+\mathrm{a}++ \\
\text { com mitoses } \\
\text { numerosas } \\
\mathrm{RPC}++\end{array}$ & $\begin{array}{l}\mathrm{SS}+\mathrm{a}++ \\
\mathrm{F}+ \\
\mathrm{RPC}+\mathrm{a}++ \\
\text { com células } \\
\text { sinciciais raras. }\end{array}$ & $\begin{array}{l}\text { Macrófagos }++ \text {, } \\
\text { linfócitos }++ \text {, } \\
\text { neutrófilos }+ \text {, } \\
\text { neutrófilos }+ \text {, } \\
\text { neutrófilos }+ \text {, } \\
\text { fibrina }(+) \text { e } \\
\text { eosinófilos }(+) \\
\text { nos SS e RPC }\end{array}$ & $\begin{array}{l}\mathrm{SS}+\mathrm{a}++ \\
\text { Cápsula }+\end{array}$ & $\begin{array}{l}\text { Células sinciciais, em quantidade mode- } \\
\text { rada, nos folículos e inclusões intracito- } \\
\text { plasmáticas raras em macrófagos }\end{array}$ \\
\hline Suíno 4 & $\begin{array}{l}\mathrm{F}++\mathrm{a}+++ \\
\mathrm{RPC}++\mathrm{a}+++\end{array}$ & $\begin{array}{l}\mathrm{F}(+) \\
\mathrm{a}++\end{array}$ & - & $(+)$ & $\begin{array}{l}\text { Linfoplasmocitá- } \\
\text { rio }+ \text {, nos SS, } \\
\text { RPC e cápsula }\end{array}$ & SS $(+) a+$ & $\begin{array}{l}\text { Presença de raras células sinciciais em } \\
\text { região para-cortical. } \\
\text { 9692I - depleção marcada e edema. } \\
\text { 29694D - linfonodos mesentéricos com } \\
\text { marcada congestão } \\
\text { 29695F - leve hemossiderose }\end{array}$ \\
\hline Suíno 5 & - & - & $\mathrm{F}+$ & $\begin{array}{l}\text { SS }(+) \\
\operatorname{RPC}(+)\end{array}$ & $\begin{array}{l}\text { Macrófagos }+, \\
\text { neutrófilos }++ \text {, } \\
\text { linfócitos }+, \\
\text { hemácias }++ \\
\text { nos SS e cápsula }\end{array}$ & SS $(+)$ & $\begin{array}{l}\text { Presença de raras células sinciciais em } \\
\text { região para-cortical. }\end{array}$ \\
\hline
\end{tabular}


Quadro 3. Surto de Circovirose (Síndrome Definhante Multissistêmica de Suínos Desmamados) no estado do Rio de Janeiro. Achados histopatológicos nos pulmões

\begin{tabular}{|c|c|c|c|c|c|c|c|c|c|}
\hline Animal & $\begin{array}{l}\text { Pneumonia in- } \\
\text { tersticial lin- } \\
\text { fo-histiocítica }\end{array}$ & $\begin{array}{l}\text { Inflamação ao re- } \\
\text { dor de brônquios/ } \\
\text { bronquíolos }\end{array}$ & $\begin{array}{l}\text { Proliferação } \\
\text { de pneumó- } \\
\text { citos tipo II }\end{array}$ & $\begin{array}{c}\text { Fibrose } \\
\text { intersticial }\end{array}$ & $\begin{array}{l}\text { Broncopneu- } \\
\text { monia neu- } \\
\text { trofílica }\end{array}$ & Enfisema & Edema & Congestão & Observação \\
\hline Suíno 1 & $\begin{array}{l}\text { a }++ \text { a }+++, \\
\text { localmente ex- } \\
\text { tensiva a difu- } \\
\text { sa, c/ raras cé- } \\
\text { lulas sinciciais }\end{array}$ & +linfo-histiocítica & $\begin{array}{c}+\mathrm{a}++\mathrm{e} \\
\text { tumefação }\end{array}$ & $(+) a+$ & $+a++$ & $+a++$ & $(+)$ & I & $\begin{array}{l}\text { Tumefação de pneumócitos tipo I }++ \\
\text { Destruição do BALT }++ \\
\text { Leucocitostase monocítica. Monóci- } \\
\text { tos ativados. Degeneração e necrose } \\
\text { leves de células da parede dos vasos; } \\
\text { vasculite incipiente. Inflamação mo- } \\
\text { nonuclear intersticial difusa com mui- } \\
\text { tos macrófagos, por vezes com exsu- } \\
\text { dação fibrinosa, provocando espessa- } \\
\text { mentos dos septos. Fibrose interlo- } \\
\text { bular leve. Bronquiolite obliterante (+) }\end{array}$ \\
\hline Suíno 2 & $\begin{array}{l}+ \text { a }++ \text { princi- } \\
\text { palmente ao re- } \\
\text { dor de brônqui- } \\
\text { os e bronquío- } \\
\text { los ou local- } \\
\text { mente extensi- } \\
\text { va, com células } \\
\text { sinciciais raras }\end{array}$ & $\begin{array}{c}+\mathrm{a}++ \\
\text { mista }\end{array}$ & + & $(+) a++$ & + & $+a++$ & $(+)$ & $(+)$ & $\begin{array}{l}\text { Hiperplasia do BALT } \text { B }^{\mathrm{b}}++ \\
\text { Bronquiolite obliterante }+ \\
\text { Fibrose interlobular e na pleura. } \\
\text { Parte dos lóbulos muitos afetados } \\
\text { pela inflamação, outros pouco afe- } \\
\text { tados }\end{array}$ \\
\hline Suíno 3 & $\begin{array}{l}++ \text { a }+++ \text { ao } \\
\text { redor de brôn- } \\
\text { quios e bron- } \\
\text { quíolos ou lo- } \\
\text { calmente exten- } \\
\text { siva a difusa, } \\
\text { com raras célu- } \\
\text { las sinciciais }\end{array}$ & $\begin{array}{c}+ \text { a }++ \text { mis- } \\
\text { ta com al- } \\
\text { guns eosi- } \\
\text { nófilos }\end{array}$ & + & $+a+$ & ++ & $(+)$ & $+\mathrm{a}++$ & ++ & $\begin{array}{l}\text { Tumefação de pneumócitos tipo I + } \\
\text { a }++ \\
\text { Destruição do BALT }+ \\
\text { Presença de células sinciciais } \\
\text { Hipertrofia de músculos de Reis- } \\
\text { seisen }(+) \\
\text { Bronquiolite obliterante }(+)\end{array}$ \\
\hline Suíno 4 & $\begin{array}{l}++ \text { a }+++, \\
\text { principalmente } \\
\text { ao redor de brôn- } \\
\text { quios e bron- } \\
\text { quíolos e/ou lo- } \\
\text { calmente ex-ten- } \\
\text { siva, com raras } \\
\text { células sinci- } \\
\text { ciais }\end{array}$ & $\begin{array}{c}+ \text { a }++ \text { predo- } \\
\text { minantemente } \\
\text { linfo-plasmo- } \\
\text { citária }\end{array}$ & + & $+a++$ & ++ & $+a++$ & $(+)$ & $\begin{array}{ccc}1 \\
1 \\
1 \\
1\end{array}$ & $\begin{array}{l}\text { Destruição do BALT }+ \text { a }++ \text {. } \\
\text { Discreta hipertrofia de músculos de } \\
\text { Reisseisen. } \\
\text { Infiltração inflamatória linfo- } \\
\text { plasmocitária no epitélio bron- } \\
\text { quiolar e músculo de Reisseisen }\end{array}$ \\
\hline Suíno 5 & $\begin{array}{l}+ \text { a }+++ \text { prin- } \\
\text { cipalmente ao } \\
\text { redor de brôn- } \\
\text { quios e bron- } \\
\text { quíolos e/ou lo- } \\
\text { calmente ex- } \\
\text { tensiva }\end{array}$ & $\begin{array}{l}\text { + predominan- } \\
\text { temente linfo- } \\
\text { plasmocitária }\end{array}$ & $(+)$ & $(+) \mathrm{a}+$ & $(+) \mathrm{a}+$ & + & - & $(+)$ & $\begin{array}{l}\text { Tumefação de pneumócitos tipo I + } \\
\text { Hiperplasia do BALT }+ \\
\text { Bronquiolite obliterante }(+)\end{array}$ \\
\hline
\end{tabular}

a (+) Alteração discreta, + leve, ++ moderada, +++ acentuada.

${ }^{\mathrm{b}}$ BALT $=$ Tecido linfóide associado ao brônquio.

exame imunohistológico e pelo método do PCR de antígenos e de DNA de PCV-2, respectivamente.

De fato, as alterações microscópicas produzidas pela infecção por PCV-2 em alguns órgãos podem ser consideradas como características (Clark 1997, Kiupel et al. 1998, Morozov et al. 1998, Allan et al. 1999, Rosell et al. 1999, Zanella \& Morés 2003). Ao nosso ver porém, se analisadas em conjunto, as lesões microscópicas poderiam ser consideradas patognomônicas. Até onde sabemos não há, em suínos, outro agente, infeccioso ou

não, capaz de produzir reação inflamatória linfo-histiocítica, com células multinucleadas, principalmente em órgãos linfóides, mas também em órgãos não-linfóides (pulmão, fígado, rim), associados com corpúsculos de inclusão intracitoplasmáticos em macrófagos e células gigantes. Pulmões, fígado e rins geralmente são órgãos afetados pelo PCV-2, porém uma relação causal definitiva entre esse vírus e as lesões nesses órgãos ainda não foi totalmente estabelecida (Darwich et al. 2004). As lesões típicas em linfonodos parecem ocorrer, em maior ou menor intensida- 
Quadro 4. Surto de Circovirose (Síndrome Definhante Multissistêmica de Suínos Desmamados) no estado do Rio de Janeiro. Achados histopatológicos nos rins

\begin{tabular}{|c|c|c|c|c|c|c|c|c|c|c|c|}
\hline Animal & $\begin{array}{l}\text { Aumento } \\
\text { do filtrado }\end{array}$ & $\begin{array}{c}\text { Dilatação } \\
\text { tubular }\end{array}$ & $\begin{array}{l}\text { Degene- } \\
\text { ração em } \\
\text { gotas hi- } \\
\text { alinas }\end{array}$ & $\begin{array}{c}\text { Tumefação } \\
\text { de células } \\
\text { epiteliais } \\
\text { tubulares }\end{array}$ & $\begin{array}{c}\text { Necrose tu- } \\
\text { bular coa- } \\
\text { gulativa }\end{array}$ & $\begin{array}{l}\text { Detritos } \\
\text { celulares } \\
\text { intra-tu- } \\
\text { bulares }\end{array}$ & $\begin{array}{l}\text { Necrose } \\
\text { glome- } \\
\text { rular }\end{array}$ & $\begin{array}{l}\text { Infiltração lin- } \\
\text { fo-histiocítica } \\
\text { intersticial } \\
\text { multifocal }\end{array}$ & Fibrose $\mathrm{Cc}$ & Congestão & Observações \\
\hline Suíno 1 & $\begin{array}{l}\mathrm{TB}^{\mathrm{a}}++{ }^{\mathrm{b}} \text { a } \\
+++, \text { com } \\
\text { cilindros } \\
\text { hialinos e } \\
\text { granulares. } \\
\mathrm{GL}^{\mathrm{c}}++ \text { a } \\
+++\mathrm{c} \text { des- } \\
\text { truição e a- } \\
\text { trofia com- } \\
\text { pressiva }\end{array}$ & ++ & $+a++$ & $+a++$ & $\begin{array}{l}+ \text { a }++ \\
\text { com células } \\
\text { em picnose } \\
\text { e cariorrexia }\end{array}$ & ++ & ++ & $\begin{array}{l}++ \text { a }+++ \\
\text { com células } \\
\text { sincicia is } \\
(+) \text { e eosi- } \\
\text { nófilos }(+)\end{array}$ & $\begin{array}{l}+ \text { a }++ \\
\text { ao redor } \\
\text { de } \mathrm{GL} \text {, de } \\
\text { focos infla- } \\
\text { matórios e } \\
\text { na cápsula }\end{array}$ & $\begin{array}{l}r \\
\text { e } \\
\text { e } \\
\text { a }\end{array}$ & $\begin{array}{l}\text { Lesões mais marcadas no } \\
\text { córtex e região córtico-me- } \\
\text { dular. Leve megalocitose } \\
\text { em células epiteliais tubula- } \\
\text { res, com presença de gotas } \\
\text { hialinas. Trombo em capi- } \\
\text { lares glomerulares com } \\
\text { exsudação fibrinosa }+ \text {, } \\
\text { hemácias }++ \text {, detritos ce- } \\
\text { lulares }(+)\end{array}$ \\
\hline Suíno 2 & - & - & - & $(+)$ & - & - & - & $\begin{array}{l}+\mathrm{a}++ \text { com } \\
\text { plasmócitos }\end{array}$ & $(+)$ & $(+)$ & $\begin{array}{l}\text { Inflamação principalmente } \\
\text { ao redor de glomérulos, va- } \\
\text { sos e túbulos. Lesão mais } \\
\text { acentuada na região córti- } \\
\text { co-medular }\end{array}$ \\
\hline
\end{tabular}

$\begin{array}{lllllll}\text { Suíno } 3 & (+) & - & - & (+) & - & (+)\end{array}$

$(+)$

$(+) \mathrm{a}+++\mathrm{a}+++\mathrm{a}++$ Lesões inflamatórias mais graves na região córticomedular, principalmente ao redor de vasos e de glomérulos, por vezes, provocando dilatação dos últimos; fibrose mais marcada na região medular. raras células sinciciais.

Suíno 4

$+\mathrm{a}++,+\mathrm{a}++$
com raras
células sin-
ciciais

$+\mathrm{a}++$ $+\quad$ Lesões mais freqüentes na região córtico-medular

$(+)$

Lesões mais freqüentes na região córtico-medular. Infiltração inflamatória, principalmente, ao redor de vasos, túbulos e glomérulos

\footnotetext{
${ }^{\mathrm{a}} \mathrm{TB}=$ Túbulo.

b $(+)$ Alteração discreta, + leve, ++ moderada, +++ acentuada.

${ }^{\mathrm{c}} \mathrm{GL}=$ Glomérulo,
}

de, em todos os animais com SDMSD, porém as lesões hepáticas e renais estão presentes em 75\% dos casos (Clark 1997, Rosell et al. 1999). No presente estudo, pneumonia intersticial, focos de infiltração linfo-histiocítica nos rins e hepatite mononuclear periportal (linfo-histiocítica em $80 \%$ dos casos e linfo-plasmocitária em $20 \%$ dos casos), em maior ou menor grau, foram observadas em todos os animais; Rosell et al. (1999) também verificaram essa mesma freqüência nos pulmões e no fígado, porém a infiltração inflamatória nos rins só foi vista em $50 \%$ dos animais.

Observamos ainda peri-vasculite (3/5) e vasculite linfohistiocitária (2/5), meningite linfo-histiocitária (2/5), microgliose (2/5), discreta inflamação mononuclear na cápsula da hipófise (1/5) no sistema nervoso central e leve infiltração linfoplasmocitária na mucosa e/ou submucosa do intestino (3/5), na submucosa do esôfago (2/5), na medula óssea (2/5), em glândula salivar (1/5) e ductos pancreáticos (1/5); adicionalmente verificamos infiltração linfo-histiocítica na própria e no músculo detrusor da bexiga (1/5) e no estômago (1/5). Algumas dessas lesões, embora não-características, vem sendo observadas em outros surtos de SDMSD (Kiupel et al. 1998, Morozov et al. 1998, McNeilly et al. 1999, Rosell et al. 1999, Sorden 1999, Zanella \& Morés 2003).

Nos animais avaliados constatamos uma variação da intensidade e da distribuição das lesões em órgãos linfóides e nãolinfóides; tal achado pode estar relacionado à resistência individual dos animais, uma vez que no presente surto os animais apresentavam idade semelhante, o que está de acordo com o verificado por outros autores (Rosell et al. 1999, Pescador et al. 2003).

Nesse estudo, a enfermidade cursou com depleção linfóide em áreas foliculares e parafoliculares nos linfonodos e, por ve- 
Quadro 5. Surto de Circovirose (Síndrome Definhante Multissistêmica de Suínos Desmamados) no estado do Rio de Janeiro. Achados histopatológicos no fígado

\begin{tabular}{|c|c|c|c|c|c|c|c|c|c|}
\hline Animal & $\begin{array}{l}\text { Inflamação lin- } \\
\text { fo-histiocítica } \\
\text { peri-portal }\end{array}$ & $\begin{array}{l}\text { Tumefação } \\
\text { hepatócitos }\end{array}$ & $\begin{array}{l}\text { Necrose individual } \\
\text { ou de grupos } \\
\text { de hepatócitos }\end{array}$ & Fibrose & $\begin{array}{l}\text { Céls infl em } \\
\text { sinuóides }\end{array}$ & $\begin{array}{l}\text { Dilatação dos } \\
\text { sinuóides }\end{array}$ & Congestão & $\begin{array}{l}\text { Eritrofa- } \\
\text { gocitose }\end{array}$ & Observações \\
\hline Suíno 1 & $\begin{array}{l}\text { a }+ \text { a }++ \text {; tam- } \\
\text { bém ao redor } \\
\text { da veia cen- } \\
\text { trolobular }+\end{array}$ & + & $\begin{array}{l}+ \\
\text { focos de necrose } \\
\text { fibrinóide }(+)\end{array}$ & $\begin{array}{l}\text { peripor- } \\
\text { tal }+ \\
\text { perilobu- } \\
\text { lar }+\end{array}$ & $\begin{array}{l}\text { macrófagos } \\
++ \\
\text { célula sin- } \\
\text { cicial }(+)\end{array}$ & $+a++$ & Difusa ++ & $+a++$ & $\begin{array}{l}\text { Inclusões víricas intracito- } \\
\text { plasmáticas em células de } \\
\text { Kupffer e células sinciciais }\end{array}$ \\
\hline Suíno 2 & - & + & - & - & - & - & Difusa + & - & $\begin{array}{l}\text { Discreta infiltração linfo- } \\
\text { plasmocitária peri-portal }\end{array}$ \\
\hline
\end{tabular}

$\begin{array}{cl}\text { Suíno } 3 & +\mathrm{a}++\mathrm{e}+\mathrm{a}++ \\ & \text { multifocal } \\ & \text { também ao re- } \\ & \text { dor da veia cen- } \\ & \text { trolobular }(+)\end{array}$

Suíno 4

$(+)$

Suíno 5

$+$

$\overline{\text { a }(+) \text { Alteração discreta, }+ \text { leve }},++$ moderada, +++ acentuada.

\begin{abstract}
$(+)$ peri-
portal e

perilobular
\end{abstract}

$(+)$ peri- Macrófagos

portal e $+a++$

perilobular: Neutrófilos

$(+)$ plasmocitária peri-portal

zes, em folículos do baço e da placa de Peyer, indicando que ambos, linfócitos T e B, foram afetados, como tem sido descrito em outros estudos (Morozov et al. 1998, Rosell et al. 1999).

Alguns autores (Clark 1997, Segalés et al. 1998) sugerem que as lesões de pele fazem parte da SDMSD, outros já associam essas lesões e as lesões renais apenas à Síndrome da Nefropatia e Dermatite Porcina (SNDP), o que ainda não está completamente esclarecido. Madec et al. (2000) são da opinião que lesões deste tipo não são regularmente observadas nos surtos de SDMSD.

O Suíno 1, primeiro animal enviado para necropsia, apresentava lesões cutâneas (exame clínico) e renais, bem como vasculite no rim e, até mesmo, no sistema nervoso central. Embora a pele desse animal não tenha sido coletada durante a necropsia, pois até esse momento não havia suspeita de infecção por PCV-2, é possível que o mesmo tenha desenvolvido um quadro idêntico à síndrome descrita como SNDP. De qualquer forma, esse animal apresentava vasculite, principal lesão na SNDP, que, segundo a literatura, está associada à reação individual imunomediada de alguns suínos (Smith et al. 1993, White \& Higgins 1993, Harding 2004).

Lesões granulomatosas, com presença de células gigantes multinucleadas, não são comuns em porcos, porém podem ser determinadas por fungos ou bactérias como Mycobacterium spp e Salmonella choleraesuis var. kunzendorf (Barker et al. 1993). Em ambos os casos, todavia, não há presença dos característicos corpúsculos de inclusão basofílicos intra-citoplasmáticos. De qualquer forma, as colorações especiais para bactérias álcoolácido resistentes (Ziehl-Neelsen) e para fungos (Ácido periódico de Schiff - PAS) em linfonodos e pulmões foram negativas. No caso de infecção por Salmonella spp, podem ocorrer lesões granulomatosas no fígado (nódulos paratifóides) e linfonodos, porém o processo pneumônico que ocorre nessa enfermidade é de natureza embólica (Barker et al. 1993) e nela não existem as lesões, nem as inclusões víricas que ocorrem na SDMSD.

Se considerarmos, porém, apenas o quadro clínico ou necroscópico, a infecção pelo PCV-2 deve ser diferenciada de outras enfermidades como a pneumonia enzoótica suína, a pleuropneumonia por Haemophilus, a síndrome respiratória e reprodutiva porcina (SRRP) e a infecção por Erysipelothrix rhusiopathiae, de forma que os clínicos devem ficar atentos para essa nova enfermidade.

Realmente, muitas das vezes, dispnéia, tosse, respiração com a boca aberta e outras alterações respiratórias podem ser bem envidentes na SDMSD, principalmente, quando há infeç̧ões bacterianas secundárias. Nos animais infectados por Mycoplasma hyopneumoniae, há sintomas respiratórios, porém, podendo afetar todas as faixas etárias (Dungworth 1993). Diferentemente da SDMSD, em áreas não-endêmicas, a morbidade e a mortalidade são altas na micoplasmose (Dungworth 1993), no entanto, embora os animais apresentem pneumonia bronco-intersticial, seguida de broncopneumonia supurativa com marcada hiperplasia do BALT (tecido linfóide associado ao brônquio), essa última não cursa com marcada linfadenopatia generalizada, nem há presença de células gigantes e inclusões víricas, como ocorre nos casos de SDMSD. Além disso, há que se considerar que a pneumonia enzoótica é responsiva a antibióticos como a tilosina, ao contrário da SDMSD (Dungworth 1993). A infeccão associada por Mycoplasma e PCV-2, porém, pode ocorrer. 
Quadro 6. Surto de Circovirose (Síndrome Definhante Multissistêmica de Suínos Desmamados) no estado do Rio de Janeiro. Achados histopatológicos em órgãos diversos

Animal Órgãos diversos

Suíno 1 Baço: depleção linfóide $+++^{\mathrm{a}}$, com inflamação histiocítica em folículos ++ , eritrofagocitose + , congestão ++ e presença de macrófagos binucleados + . Inclusões citoplasmáticas em macrófagos.

Intestino delgado: depleção linfóide em placa de Peyer +++ , inflamação linfo-histiocítica com céls sinciciais em folículos. Há edema na serosa + , enterite mista com alguns eosinófilos atingindo também a submucosa + , fibrose da própria + e congestão de vasos da serosa ++ .

Intestino grosso: infiltração linfo-histiocítica em agregados linfóides na submucosa, com presença de célula sincicial.

Cérebro: peri-vasculite linfo-histiocitária meningeana e submeningeana $(+)$ a + , com meningite linfo-histiocitária + a ++ , edema com presença de proteínas nas meninges +++ e espaços meningeanos +++ e congestão meningeana + . Há edema de astrócitos $++\mathrm{a}+++$ com lise $(+)$, vacuolização, tumefação e lise neuronal $(+)$, necrose incipiente de neurônios do córtex $(+)$, edema da substância cinzenta ++ , edema peri-vascular ++ (córtex, substância cinzenta e região submeningeana), leucocitostase mononuclear + e tumefação de células endoteliais $+\mathrm{a}++$.

Cerebelo: peri-vasculite linfo-histiocítica + a ++ em vasos da meninge, congestão meningeana + , vasculite linfo-histiocítica + , com ativação trombocítica $(+)$ e presença de fibrina agregada à parede do vaso.

Coração: edema intersticial + , leucocitostase linfocítica $(+)$, atrofia de miócitos $(+)$ e necrose individual de fibras $(+)$.

Pâncreas: infiltração linfo-plasmocitária ao redor de ductos (+)

Estômago: sem alterações significativas.

Suíno 2 Baço: infiltração macrofágica em seios trabeculares + e depleção linfóide +

Intestino delgado e intestino grosso: infiltração inflamatória linfo-plasmocitária na mucosa e submucosa (+).

Tonsila: hiperplasia folicular $(+)$ e inflamação neutrofílica em criptas + .

Coração, glândula salivar, útero, ovário, esôfago, timo, bexiga, utereter, adrenal, pâncreas e língua: sem alterações significativas.

Suíno 3 Baço: infiltração linfo-histiocítica multifocal em folículos e em região inter-folicular + , depleção linfóide + , fibrose $(+)$ e congestão $(+)$.

Medula óssea: infiltração plasmocitária.

Intestino delgado: infiltração linfo-histiocítica em placa de Peyer $(+)$, edema da própria + e hipersecreção mucosa ++ . Intestino grosso: inflamação linfo-plasmocitária na mucosa + .

Tonsila: infiltração histiocitária interfolicular $+\mathrm{a}++$, hiperplasia folicular $+\mathrm{a}++$, inflamação aguda em criptas + e inflamação mista abaixo da mucosa + .

Cérebro: Corno de Amon - peri-vasculite linfo-histiocítica + , ponte - encefalite linfo-histiocítica + , córtex - meningite linfohitiocítica $(+)$, edema de astrócitos ++ com lise, vacuolização, tumefação e lise neuronal + , necrose incipiente de neurônios do córtex $(+)$, meningite linfo-histiocitária ++ , edema com glóbulos de proteína nas meninges +++ e espaços meningeanos +++ . Edema da substância cinzenta ++ , edema perivascular ++ (córtex, substância cinzenta e submeningeano), leucocitostase mononuclear + , tumefação de células endoteliais + a ++ e congestão ++ .

Cerebelo: perivasculite linfo histiocítica nos vasos meninge + , focos de microgliose ou perivasculite $(+)$, vasculite mononuclear a linfo-histiocítica $+\mathrm{a}++$. Base do cerebelo: inflamação perivascular linfohistiocítica ++ .

Hipófise: inflamação mononuclear na cápsula $(+)$.

Coração: edema entre as fibras cardíacas + , edema no endocárdio $(+)$.

Estômago: inflamação linfo-histiocítica focal na serosa $(+)$, edema da própria +

Bexiga: infiltração inflamatória linfo-histiocítica no interstício do músculo detrusor $(+)$.

Esôfago: perivasculite linfocítica na submucosa $(+)$, leucocitostase $(+)$, adenite linfo-plasmocitária em glândula salivar $(+)$.

Tireóide: aumento na produção de colóide + .

Músculo esquelético: degeneração e necrose de fibras ++ (decúbito?).

Pele, pâncreas, olho, ovário, ureter, glândula salivar, língua, medula óssea (junção costo-condral), cornetos nasais e traquéia: sem alterações significativas.

Suíno 4 Baço: depleção linfóide + a ++ , com infiltração inflamatória linfo-plasmocitária entre os folículos + a ++ , congestão $(+)$. Tonsila: infiltração linfo-histiocítica + , depleção linfóide $(+)$

Intestino delgado e grosso: congestão e hemorragia na mucosa e submucosa ++ , infiltração linfo-plasmocitária + a ++ na mucosa e submucosa, com fibrose da última + e lesões em vilosidades, que apresentam-se recobertas por "detritos celulares" e fibrina. Medula óssea: infiltração linfo-plasmocitária $(+)$.

Cérebro: raros focos de gliose e de inflamação linfo-histiocítica na substância branca (+). Cerebelo: sem alterações significativas. Pâncreas: infiltração linfo-plasmocitária ao redor de alguns ductos $(+)$.

Traquéia: infiltração linfo-plasmocitária na submucosa $+\mathrm{a}++$.

Esôfago: perivasculite linfo-plasmocitária $(+)$.

Coração: necrose incipiente de algumas fibras $(+)$ e hemorragias epicárdicas + .

Tireóide: aumento da produção de colóide $(+)$.

Pele, bexiga, músculo esquelético, glândula salivar: sem alterações significativas.

Suíno 5 Baço: hiperplasia linfóide na região na zona marginal $(+)$, focos de inflamação macrofágica principalmente na polpa branca + , congestão $(+)$, hemossiderose $(+)$

Tonsila: hiperplasia folicular $(+)$.

Intestino grosso e delgado: infiltração inflamatória linfo-plasmocitária na submucosa e mucosa $(+)$.

Cérebro: congestão dos vasos da meninge do córtex ++ . Cerebelo e hipófise: sem alterações significativas.

Coração, adrenal, estômago, olho: sem alterações significativas.

$\overline{\mathrm{a}}(+)$ Alteração discreta, + leve,++ moderada, +++ acentuada. 
A pleuropneumonia causada por Actinobacillus pleuropneumoniae (anteriormente denominado Haemophilus pleuropneumoniae), geralmente cursa com morbidade e mortalidade altas em suínos desmamados e caracteriza-se por broncopneumonia fibrinosa, com pleurite, em especial na porção dorsal dos lobos caudais e tendência a seqüiestros nos animais que sobrevivem. Nos casos de evolução mais crônica podem ocorrer, além da pneumonia, pleurite e pericardite com aderências (Dungworth 1993). Lesões com essa distribuição não têm sido observadas na SDMSD.

Suínos afetados pela SRRP evidenciam algumas características epidemiológicas e clínicas (distúrbios respiratórios, reprodutivos e no ganho de peso dos animais) semelhantes à encontradas em suínos infectados pelo PCV-2. A linfadenopatia granulomatosa generalizada, as inclusões víricas intracitoplasmáticas e a presença de células sinciciais, porém, não ocorrem na SRRP (Benfield et al. 1999). A SRRP ainda não foi diagnosticada no Brasil (Moreno et al. 2003).

A infecção por Erysipelothrix rhusiopathiae pode causar doença aguda/subaguda ou crônica, que afeta, principalmente, animais com menos de 3 meses ou com mais de 3 anos de idade. A forma aguda é caracterizada por lesões cutâneas sob a forma de figuras geométricas avermelhadas ("pele de diamante"), determinadas por trombos em vasos da papila cutânea com presença de bactérias, associadas à marcada congestão do baço (Wood 1999). Animais que não morrem ou que tem infecção subclínica podem apresentar a forma crônica da doença que cursa com lesões articulares, semelhantes às da artrite reumatóide, e endocardite vegetante (Wood 1999). Nos casos mais leves ou na infecção subclínica, a enfermidade pode ser confundida com a infecção pelo PCV-2, porém a erisipela suína não provoca lesões como linfadenite granulomatosa e nem a pneumonia intersticial característica da SDMSD.

Apesar das características epidemiológicas e clínicas, bem como parte dos achados anátomo-patológicos da SDMSD serem diferentes dos que ocorrem na peste suína clássica e na peste suína africana, algumas características histológicas como a vasculite mononuclear, a leucocitostase hepática e a necrose de linfócitos podem ser comuns a essas três enfermidades. Ambas as pestes suínas, porém, não cursam com formação de células gigantes com inclusões intra-citoplasmáticas, além de evidenciarem, usualmente, hemorragias conspícuas em diversos órgãos. A necrose linfocítica na peste suína ocorre com mais frequiência nas regiões parafoliculares (Sanchez-Vizcaino 1999), diferentemente da SDMSD.

$\mathrm{O}$ isolamento de outros agentes como o parvovírus porcino (PPV) e o vírus da influenza suína (SIV) não foi tentado, de forma que não podemos descartar completamente a possibilidade de ter ocorrido co-infecção do PCV-2 com esses agentes. De qualquer forma, esses agentes, constantemente mencionados na literatura como co-infectantes do PCV-2 não parecem ser importantes aqui no Brasil. A pesquisa de antígenos de PPV, através da técnica de PCR, não demonstrou presença desse agente em suínos com doenças respiratórias em diversos Estados no Brasil (Moreno et al. 2003). O SIV, quando único agente, provoca sintomas como tosse grave e falta de apetite em suínos de várias idades, porém os sintomas costumam desaparecer em uma se- mana, sem maiores problemas (Easterday \& Van Reeth 1999).

Com relação aos aspectos epidemiológicos, verificamos, no presente surto, que a doença afetou, em especial, animais de aproximadamente 4 meses, coincidindo com a idade observada por outros autores; 7 a 15 semanas (Harding et al. 1998, Darwich et al. 2004, Segalés et al. 2004) e 8 a 16 semanas (Allan \& Ellis 2000). Lukert \& Allan (1999), observaram essa enfermidade em animais mais jovens (6-8 semanas de idade).

Segundo Rosell et al. (1999), em casos com evolução crônica de SDMSD podem ocorrer enterite, nefrite intersticial, imunossupressão e insuficiência hepática. Observamos os dois primeiros tipos de lesão, porém nossos animais apresentaram, aparentemente, evolução que variou entre aguda e crônica.

Durante a visita realiza à granja em 8.4.02, verificou-se que a mortalidade total foi de $16,5 \%$; segundo informações do proprietário, até aquele momento, não haviam morrido animais adultos. Se avaliarmos a mortalidade, considerando apenas os animais que encontravam-se em fase de crescimento, esta sobe para $20 \%$, taxa superior à de $10 \%$ verificada por Madec et al. (2000), que apenas avaliaram a mortalidade em porcos em crescimento.

De acordo com Madec et al. (2000), outros fatores, além da infecção vírica, devem influenciar na vulnerabilidade das leitegadas ao PCV-2, já que há uma forte expressão individual da doença. Em nosso surto, parte dos porcos não exibiu qualquer sintoma, enquanto outros foram severamente afetados, achado semelhante ao observado por Madec et al. (2000). Acreditamos que a influência ambiental e o manejo deficitário tenham exercido um importante papel na gravidade desse surto. Por isso, medidas profiláticas como melhoria da higiene, segregação de classes, melhor ventilação e redução do número de animais devem ser implementadas para evitar ou diminuir a ocorrência da enfermidade. A mistura de animais de diferentes leitegadas também aumenta os riscos de transferência de patógenos, o que poderia interferir com a blastogênese de linfócitos (Deguchi \& Akuzawa 1998). Além disso, mistura de animais de diferentes idades e de diversas origens é um fator importante na transmissão da doença (Rose et al. 2003). No presente relato ocorreram ambos os fatores acima citados; na propriedade onde aconteceu o surto, houve introdução de animais oriundos de São Paulo e do Paraná, Estados nos quais antígenos de PCV-2 já foram detectados (Castro et al. 2003, Pinto et al. 2003b, respectivamente).

Provavelmente, a introdução do PCV-2 no Brasil ocorreu a partir de Santa Catarina, Estado com grande concentração de suínos, e espalhou-se para outros Estados como Paraná (Pinto et al. 2003b), Rio Grande do Sul (Zanella et al. 2003b), São Paulo (Castro et al. 2003) e Minas Gerais (Pinto et al. 2003a) onde antígenos de PCV-2 já foram detectados; no Mato Grosso do Sul detectaram-se apenas antígenos de PCV-1 (Castro et al. 2003).

De qualquer forma, um recente estudo sorológico no Canadá demonstrou que o vírus está presente em todas as propriedades e o desenvolvimento de anticorpos demonstra que PCV-2 circula ativamente em estágios pós-desmame (engorda/terminação) e que a transmissão horizontal é significativa. A presença de anticorpos de PCV-2 em granjas onde não havia sinais clínicos de SDMSD indicaria que o PCV-2 não é capaz de provocar sozinho doença clínica severa. Por outro lado, Krakowka et al. (2001) verificaram que, isoladamente, $\mathrm{o} \mathrm{PCV}-2$ pode causar lesões gra- 
ves, quando o animal sofre imunoestimulação, por vacinas ou drogas.

A presença de DNA de PCV-2 detectada pelo PCR apenas no pulmão do Suíno 1, não significa que só esse suíno tivesse desenvolvido a enfermidade ou que o vírus estivesse localizado apenas nesse órgão. Na literatura é freqüente a menção de achados negativos por essa técnica em animais que sofreram de circovirose e apresentaram lesões características (Kiatipattanasakul-Banlunara et al. 2002, Zanella \& Morés 2003). Isso pode ser explicado pela falha na amplificação pelo método do PCR em material submetido à fixação por formalina por períodos prolongados ou pelo próprio efeito que o formol causa na deteç̧ão pelo PCR (Kiatipattanasakul-Banlunara et al. 2002).

De acordo com esses últimos autores, a falha na amplificação de amostras fixadas por longo período pode ser devida à degradação da seqüência-alvo pela fixação por formalina. $\mathrm{O}$ autor relata que, em seu estudo, nenhum produto foi amplificado em 4 amostras embebidas em formol, por período maior do que 4 meses. Nesse estudo foram utilizadas 12 amostras formolizadas, entre 1 e 8 meses de fixação; todas as amostras com período superior a 4 meses de fixação foram negativas pelo PCR. De fato, certos inibidores contra polimerases de DNA, em tecido fixado por formalina, possivelmente afetam a amplificação pelo PCR (Kiatipattanasakul-Banlunara et al. 2002). Em nosso estudo, os órgãos dos Suínos 2, 3, 4 e 5 permaneceram por mais de 6 meses em formalina, o que pode ter prejudicado a detecção pelo PCR dessas amostras. A ausência ou menor quantidade de DNA ou Ag vírico, observada em algumas amostras, também pode estar associada ao estágio da doença (Sato et al. 2000, Zanella \& Morés 2003) e, até mesmo, a diferentes cepas do PCV-2 (Sato et al. 2000, Zanella \& Morés 2003). Embora DNA de PCV-2 não tenha sido amplificado a partir do material de todos os animais de um surto, o resultado positivo pelo PCR de parte dos animais e as lesões histológicas típicas, juntos, são considerados consistentes para o diagnóstico de SDMSD nesse episódio (Zanella \& Morés, 2003).

Até mesmo algum componente inibidor presente no preparado para o PCR (os testes pelo PCR em blocos parafinados foram iniciados a pouco tempo no Centro Nacional de Pesquisa em Suínos e Aves - Embrapa) pode provocar falsos-negativos (Zanella, 2004, comunicação pessoal).

Segundo Kim \& Chae (2003), certos procedimentos que envolvem o pré-tratamento com rápida digestão por proteinase $\mathrm{K}$ e utilização de aparelho termociclador ("thermocycler"), devem ser seguidos durante o processamento das amostras embebidas em formalina ou parafinizadas, sob pena de ocorreram resultados falso-negativos.

As amostras foram analisadas por reação externa e interna pelo PCR, já que Pinto et al. (2003b) verificaram que a reação externa pelo PCR pode não ser suficiente para obtenção de produtos amplificados, provocando resultados negativos em tecidos congelados (10/18), parafinizados (13/18) e formolizados (18/18).

Foram evidenciadas algumas alterações nos exames hematológicos e bioquímicos. A anisocitose e a policromasia leves, por nós verificadas, nos Suínos 2, 4 e 5, podem ocorrer em casos de anemia regenerativa e, até mesmo, em animais normais
(Coles 1984), no entanto, é difícil estabelecer, se há ou não, em nossos casos, correlação, entre essa e a infecção vírica. No Suíno 2 , o número de linfócitos no sangue estava levemente aumentado, havia neutropenia relativa e nos três animais (Suínos 2, 4 e 5) e a leucometria total estava levemente baixa se comparada com o valor médio desta, para animais nesta faixa etária (Coles 1984); em contraste, Segalés \& Domingo (2002) e Darwich et al. (2003) verificaram baixos níveis de linfócitos, com aumento do número de monócitos e neutrófilos, não havendo alteração no número total de leucócitos. Variações nos números de células da série branca têm sido observadas em vários surtos e podem ser atribuídas à fase e à gravidade da doença, a infecções secundárias e, até mesmo, a resistência individual do animal (Segalés \& Domingo 2002, Darwich et al. 2003, Nielsen et al. 2003). Os níveis de globulinas estavam diminuídos nos 3 animais (Suínos 2, 4 e 5) avaliados; essse achado pode ocorrer em animais com imunossupressão (Coles 1984). Os níveis de TGP (46.50 U/L) e fosfatase alcalina $(55.20 \mathrm{U} / \mathrm{L})$ estavam aumentados no Suíno 2 , talvez este aumento esteja associado à leve lesão hepática. Por outro lado, animais jovens, com menos de 9 meses de idade, podem apresentar níveis de fosfatase alcalina próximos a $40 \mathrm{U} / \mathrm{L}$, que seria considerado normal (Coles 1984); se considerarmos esse fato, os níveis de fosfatase alcalina neste animal, estariam apenas levemente aumentado. Nos Suínos 2, 4 e 5 a bilirrubina indireta estava um pouco aumentada $(0,63,0,76$ e $0,67 \mathrm{mg} / \mathrm{DL}$, respectivamente), acreditamos que este aumento não seja significativo; a bilirrubina indireta pode estar aumentada em processos hemolíticos e em jejum prolongado (Coles 1984).

A existência de lesões linfóides e a associação da SDMSD com muitas infecções oportunistas e secundárias (Darwich et al. 2004), sugerem que o envolvimento do sistema imune na patogênese da SDMSD tem papel central, já que muitos porcos são infectados e apenas alguns ficam doentes. Ainda é difícil responder às perguntas: o que o vírus causa nas células e como a resposta imune contribui para o desenvolvimento da síndrome? Além disso, muitos animais que estão em recuperação apresentam sinais clínicos e lesões linfóides semelhantes aos encontrados em estágios iniciais de SDMSD (Quintana et al. 2001), o que torna difícil avaliar o que é agudo ou crônico nessa síndrome. Segundo Darwich et al. (2004), muitos animais infectados com PCV-2 não desenvolvem sinais clínicos, de forma que o termo agudo ou crônico deve ser utilizado, restritamente, quando há sintomas clínicos; a alternativa é empregar termos como fase final e inicial da doença (Darwich et al. 2004).

É evidente a necessidade de estudos futuros, para um melhor entendimento da patogenia da SDMSD e sua correlação com outras doenças, já que a circovirose é uma doença emergente, que vem causando grandes prejuízos à suinocultura mundial.

Atualmente não se conhece, de maneira clara e inequívoca, uma forma capaz de controlar a circovirose suína de modo eficiente, porém boas medidas de manejo, como melhoria da higiene e a redução do estresse dos animais podem diminuir a infecção das granjas (Zanella et al. 2003a).

\section{REFERÊNCIAS}

Allan G.M. \& Ellis J. 2000. Porcine circovirus: a review. J. Vet. Diagn. Invest. 12:3-14. 
Allan G.M., McNeilly F., Kennedy S., Daft B., Clark G.E., Haines D.M. \& Meehan B.M. 1998. Isolation of porcine circovirus-like viruses from pigs with a wasting disease in the USA and Europe. J. Vet. Diagn. Invest. 10:3-10.

Allan G.M., Mcneilly F.M., Meehan B.M., Kennedy S., Mackie D.P., Ellis J.A., Clark E.G., Espuna E., Saubi N., Riera P., Boetner A. \& Charreyre C.E. 1999. Isolation and characterization of circoviruses from pigs with wasting syndromes in Spain, Denmark and Northern Ireland. Vet. Microbiol.. 66:115-123.

Allan G.M., McNeilly F., McNair I., Curran M.D., Walker I., Ellis J., Konoby C., Kennedy S. \& Meehan B. 2000. Absence of evidence for porcine circovirus types 2 in cattle and humans, and lack of seroconversion or lesions in experimentally infected sheep. Arch. Virol. 145(4):853-857.

Barker I. K., Van Dreumel A.A. \& Palmer N. 1993. The alimentary system, p.1-318. In: Jubb K.V.F., Kennedy P.C. \& Palmer N. (ed.) Pathology of Domestic Animals. Vol. 2. 4th ed. Academic Press, San Diego.

Benfield D.A., Collins J.E., Dee S.A., Halbur P.G., Joo H.S., Lager K.M., Mengeling W.L., Murtaugh M.P., Rossow K.D., Stevenson G.W. \& Zimmerman J.J. 1999. Porcine reproductive and respiratory syndrome, p.201-276. In: Straw B.E.S., D'allaire S., Mengeling W.L. \& Taylor, D.J. (ed.) Diseases of Swine. 8th ed. Iowa State University Press, Ames.

Castro A.M.M.G., Ruiz V.L.A., Castro Jr F.G., Bersano J.G., Moreno A.M. \& Cortez, A. 2003. Detecção e diferenciação de circovírus suíno tipo 1 e 2 (PCV-1 e PCV-2) em suínos nas fases de creche e crescimento/terminação em diferentes Estados brasileiros e em suínos do Estado de São Paulo. Anais $11^{\circ}$ Congr. Bras. Vet. Especialistas em Suínos, Goiânia. Embrapa Suínos e Aves, Concórdia, p.107-108.

Choi C., Kim J., Kang I.J. \& Chae C. 2002. Concurrent outbreak of PMWS and PDNS in a herd of pigs in Korea. Vet. Rec. 151:484-485.

Clark E.G. 1997. Post-weaning multisystemic wasting syndrome. 1997. Proc. Annu. Meet. Am. Assoc. Swine Pract. 28:499-501.

Coles E.H. 1984. Patologia Clínica Veterinária. 3aㅗ ed. Editora Manole, São Paulo, p.566.

Darwich L., Segalés J., Domingo M. \& Mateu E. 2002. Changes in CD4 ${ }^{+}$, $\mathrm{CD}^{+}, \mathrm{CD}^{+}, \mathrm{CD}^{+}$, and immunoglobulin M-positive peripheral blood mononuclear cells of postweaning multisystemic wasting syndromeaffected pigs and age-matched uninfected wasted and healthy pigs correlate with lesions and Porcine Circovirus Type 2 load in lymphoid tissues. Clin. Diagn. Laboratory 2(9):236-242.

Darwich L., Pie S., Rovira A., Segalés J., Domingo M., Oswald I.P. \& Mateu E. 2003. Cytokine mRNA expression profiles in lymphoid tissues of pigs naturally affected by postweaning multisytemic wasting syndrome. J. Gen.Virology 84:2117-2125.

Darwich L., Segalés J. \& Mateu E. 2004. Pathogenesis of postweaning multisystemic wasting syndrome caused by Porcine circovirus 2: an immune riddle. Arch. Virology 149(5):857-874.

Deguchi E. \& Akuzawa M. 1998. Effects of fighting after grouping on plasma cortisol concentration and lymphocytes blastogenesis of peripheral blood mononuclear cells induced by mitogens in piglets. J. Vet. Med. Sci. 60:149-153.

Dungworth D.L. 1993. The respiratory system, p.539-699. In: Jubb K.V.F., Kennedy P.C., Palmer N.(ed.) Pathology of Domestic Animals. Vol. 2. 4 th ed. Academic Press, San Diego.

Easterday B.C. \& Van Reeth K. 1999. Swine Influenza, p.277-290. In: Straw B.E., D'allaire S., Mengeling W.L. \& Taylor D.J (ed) Diseases of Swine. 8th ed. Iowa State University Press, Ames.

Ellis J.A., Hassard L., Clark E., Harding J., Allan G., Willson P., Strokappe J., Martin K., McNeilly F., Meehan B., Todd D. \& Haines D. 1998. Isolation of circovirus from lesions of pigs with postweaning multisystemic wasting syndrome. Can. Vet. J. 39:44-51.

França T.N. 2004. Surto de Circovirose (Síndrome Definhante Multissistêmica de Suínos Desmamados) no Estado do Rio de Janeiro. Tese de doutorado, Univ. Fed. Rural Rio de Janeiro. 110p.

Gallian P., Biagini P. Attoui H., Cantaloube J.F., Dussol B., Berland Y., de
Micco P. \& de Lamballerie X. 2002. High genetic diversity revealed by the study of TLMV infection in French hemodialysis patiente. J. Med.Virol. 67(4):630-635.

Harding J.C. 1997. Post-weaning multisystemic wasting syndrome (PMWS): preliminary epidemiology and clinical presentation. , Proc. 28th Annu. Meet. Am. Assoc. Swine Practitioners, Quebec City, Canada, p.503.

Harding J.C.S. 2004. The clinical expression and emergence of porcine circovirus 2. Vet. Microbiol. 98(2):131-135.

Harding J.C.S., Clark E.G., Strokappe J.H., Willson P.I. \& Ellis J.A. 1998. Postweaning multisystemic wasting syndrome: Epidemiological and clinical presentation. Swine Hlth Prod. 6:249-254.

Kiatipattanasakul-Banlunara W., Tantilertcharoen R., Suzuki K., Albarenque S.M., Thanawongnuwech R., Nakayama H \& Doi K. 2002. Detection of porcine circovirus 2 (PCV-2) DNA by nested PCR from formalina-fixed tissues of post-weaning multisystemic wasting syndrome (PMWS) pigs in Thailand. J. Vet. Med. Sci. 64(5):449-452.

Kim J. \& Chae C. 2003. Expression of monocyte chemoattactant protein1 but not interleukin-8 in granulomatous lesions in lymph nodes from pigs with naturally occurring postweaning multisystemic wasting syndrome. Vet. Pathol. 40:181-186.

Kim J. \& Chae C. 2003. Expression of monocyte chemoattactant protein1 but not interleukin- 8 in granulomatous lesions in lymph nodes from pigs with naturally occurring postweaning multisystemic wasting syndrome. Vet. Pathol. 40:181-186.

Kiupel M., Stevenson G.W., Mittal S.K., Clark E.G. \& Haines D.M. 1998. Circovirus-like viral associated disease in weaned pigs in Indiana. Vet. Pathol. 35:303-307.

Krakowka S., Ellis J.A., Meehan B., Kennedy S., McNeilly F. \& Allan G.M. 2000. Viral wasting syndrome of swine: experimental reproduction of PMWS in gnotobiotics swine by co-infection with porcine circovirus-2 (PCV-2) and porcine parvovirus (PPV). Vet. Pathol. 37:254-263.

Krakowka S., Ellis J.A., McNeilly F., Ringler S., Rings D.M. \& Allan G. 2001. Activation of the immune system is the pivotal event in the production of wasting disease in pigs infected with porcine circovirus-2 (PCV-2). Vet. Pathol. 38:31-42.

Kyriakis S.C., Saoulidis K., Lekkas S., Miliotis Ch.C., Papoutsis P.A. \& Kennedy S. 2002. The effects of immuno-modulation on the clinical and pathological expression of postweaning multisystemic wasting syndrome. J. Comp. Pathol. 126:38-46.

Larochelle R., Magar R. \& D'allaire S. 2003. Comparative serologic and virologic study of commercial swine herds with and without postweaning multisystemic wasting syndrome. Can. J. Vet. Res. 67:114-120.

Lukert P.D. \& Allan G.M. 1999. Porcine circovirus, p.119-124. In: Straw B.E., D'Allaire S., Mengeling W.L., Taylor D.J (ed.) Diseases of Swine. 8thed. Iowa State University Press, Ames.

Lukert P., de Boer G.F., Dale J.L., Keese P., McNulty M.S., Randles J.W. \& Tischer I. 1995. The Circoviridae, p.166-168. In: Murphy F.A., Fauquet C.M., Bishop D.H.L., Ghabrial S.A., Jarvis A.W., Martelli G.P., Mayo M.A. \& Summers M.D. (ed.) Virus Taxonomy. Sixth Report of the International Commitee on Taxonomy of Viruses. Springer Verlag, New York.

Madec F., Eveno E., Morvan P., Hamon L., Blanchard P., Cariolet R., Amenna N., Morvan H., Truong C., Mahé D., Albina E. \& Jestin A. 2000. Postweaning multisystemic wasting syndrome (PMWS) in pigs in France: clinical observations from follow-up studies on affected farms. Livestock Prod. Sci. 63:223-233.

Magar R., Larochelle R., Thibault S. \& Lamontagne L. 2000. Experimental transmission of porcine circovirus type 2 (PCV2) in weaned pigs: a sequential study. J. Comp. Pathol. 123(4):258-269.

McNeilly F., Kennedy S., Moffett D., Meehan B.M., Foster J.C., Clarke E.G., Ellis J.A., Haines D.M., Adair B.M. \& Allan G.M. 1999. A comparison of in situ hybridization and immunohistochemistry for the detection of a new porcine circovirus in formalin-fixed tissues from pigs with postweaning multisystemic wasting syndrome (PMWS). J. Virol. Methods 80(2):123-128. 
Meehan B.M., McNeilly F., Todd D., Kennedy S. Jewhurst V.A., Ellis J.A., Hassard L.E., Clark E.G., Hanes D.M. \& Allan G.M. 1998. Characterization of novel circovirus DNAs associated with wasting syndromes in pigs. J. Gen. Virol. 79:2171-2179.

Moreno A.M., Castro M.G., Paixão R., Cortez A., Doto D.S., Leomil H., Baccaro M.R. \& Richtzenhain L.J. 2003. Associação entre circovírus suíno tipo 2 e as doenças respiratórias no Brasil. Anais 11ํㅡ. Congr. Bras. Vet. Especialistas em Suínos, Goiânia. Embrapa Suínos e Aves, Concórdia, p.101-102.

Morozov I., Sirinarumitr T., Sorden S.D., Halbur P.G., Morgan M.K., Yoon K. \& Paul P.S. 1998. Detection of a novel strain of porcine circovirus in pigs with postweaning multisystemic wasting syndrome. J. Clin. Microbiol. 36:2535-2541.

Nielsen J., Vincent I.E., Botner A., Ladekjaer-Mikkelsen A.S., Allan G.M., Summerfield A. \& McCullough K.C. 2003. Association of lymphopenia with porcine circovirus type 2 induced postweaning multisystemic wasting syndrome (PMWS). Vet. Immun. Immunopathol. 92:97-111.

Pescador C.A., Rozza D.B., Zlotowski P., Borowski S.M., Barcellos D.E. \& Driemeier D. 2003. Principais lesões histopatológicas associadas a circovirose em suínos das fases de crescimento e terminação em rebanhos suínos do Rio Grande do Sul. In: Anais $11^{\circ}$ Congr. Bras. Vet. Especialistas em Suínos, Goiânia. Embrapa Suínos e Aves, Concórdia, p.105-106.

Pinto F.F., Lobato Z.I.P., Nascimento E.F., Rocha M.A. \& Barbosa C.N. 2003a. Detecção do circovírus suíno 2 (PCV-2) em tecidos coletados de suínos do Estado de Minas Gerais utilizando a reação em cadeia da polimerase (PCR). Anais 11 Congr. Bras. Vet. Especialistas em Suínos, Goiânia. Embrapa Suínos e Aves, Concórdia, p.105-106.

Pinto F.F., Lobato Z.I.P., Nascimento E.F., Rocha M.A. \& Barbosa C.N. 2003b. Influência do processamento tecidual na detecção do circovirus suíno tipo 2 (PCV-2) utilizando a técnica de PCR. Anais 11을. Congr. Bras. Vet. Especialistas em Suínos, Goiânia. Embrapa Suínos e Aves, Concórdia, p.103-104.

Quintana J., Segalés J., Rosell C., Calsamiglia M., Rodriguez-Arrioja G.M., Chianini F., Folch J.M., Maldonado J., Canal M., Plana-Durán J. \& Domingo M. 2001. Clinical and pathological observations on pigs with postweaning multisystemic wasting syndrome. Vet. Rec. 149:357-361.

Rose N., Larour R., Le Diguerher G. \& Eveno E.J.P. 2003. Risk factors for porcine post-weaning multisystemic wasting syndrome (PMWS) in 149 French farrow-to-finish herds. Prev. Vet. Medicine 61(3):209-225.

Rosell C., Segalés J., Plana-Durán J., Balasch M., Rodriguez-Arrioja G.M., Kennedy S., Allan G.M., McNeilly F., Latimer K.S. \& Domingo M. 1999. Pathological, immunohistochemical, and in-situ hybridization studies of natural cases of postweaning multisystemic wasting syndrome (PMWS) in pigs. J. Comp. Pathol. 120(1):59-78.

Rovira M., Balasch J., Segalés L., Garcia J., Plana-Durán C., Ellerbrok H., Mankertz A. \& Domingo M. 2002. Experimental inoculation of conventional pigs with porcine reproductive and respiratory syndrome vírus and Porcine Circovirus 2. J. Virology 7(76):3232-3239.
Sanchez-Vizcaino J.M. 1999. African swine fever, p.93-102. In: Straw B.E., D’Allaire S., Mengeling W.L. \& Taylor D.J (ed.) Diseases of Swine. 8th. ed. Iowa State University Press, Ames.

Sarradell J., Perez A.M., Andrada M., Rodriguez F., Fernandes A. \& Segalés J. 2002. PMWS in Argentina. Vet. Rec. Letters 9:323.

Sato K., Shibahara T., Tshikawa Y., Kondo H., Kubo M. \& Kadota K. 2000. Evidence of porcine circovirus infection in pigs with wasting disease syndrome from 1985 to 1999 in Hokkaido, Japan. J. Vet. Med. Sci. 62(6):627-633.

Segalés J. \& Domingo M. 2002. Postweaning multisystemic wasting syndrome (PMWS) in pigs. A review. Vet. Quarterly 24:109-124.

Segalés J., Piella J., Marco E., Mateu-De-Antonio E.M., Espunã E. \& Domingo M. 1998. Porcine dermatitis and nephropathy syndrome in Spain. Vet. Rec. 142:483-486.

Segalés J., Rosell C. \& Domingo M. 2004. Pathological findings associated with naturally acquired porcine circovirus type 2 associated disease. Vet. Microbiol.. 98:137-149.

Smith W.J., Thomson J.R. \& Done S. 1993. Dermatitis/nephropathy syndrome of pigs. Vet. Rec. 132:47. (Cit. Segalés et al. 2004)

Sorden S.D. 1999. Postweaning multisystemic wasting syndrome (PMWS): a diagnostic perspective. IOWA. Disponível em: <http:// animalagriculture.org/Proceedings/1999_NatCon_Animal_Health/ PMWS\%20A\%20diagnostic\%20perspective.htm $>$. Acesso em: 11 out. 2002.

Tischer I., Rasch R. \& Tochtermann G. 1974. Chacacterization of papovarius and picornavirus-like particles in permanente pig kidney cell lines. Zentralbl. f. Bakt. Mikrobiol. Hyg. A 226:153-167.

Tischer I., Gelderblom H., Vettermann W. \& Kock M.A. 1982. A very small porcine virus with circular single-stranded DNA. Nature 295:64-66.

Trujano M., Iglesias G., Segalés J. \& Palacios J.M. 2001. PCV-2 from emaciated pigs in Mexico. Vet. Rec. Letters 8:792.

White M. \& Higgins R.J. 1993. Dermatitis nephropathy syndrome of pigs. Vet. Rec. 132:199. (Cit. Harding 2004).

Wood R.L. 1999. Erysipelas, p.419-430. In: Straw B.E.S., D’Allaire S., Mengeling W.L. \& Taylor D.J. (ed.) Diseases of Swine. 8th ed. Iowa State University Press, Ames.

Zanella J.R.C. \& Morés N. 2003. Diagnosis of post-weaning multisystemic wasting syndrome in pigs in Brazil caused by porcine circovirus. Arq. Bras. Med. Vet. Zootec. 55(5):522-527.

Zanella J.R.C., Morés N. \& Amaral A.L. 2003a. Acompanhamento de um surto de circovirose suína em granja produtora de leitões. Anais $11^{\circ}$ Congr. Bras. Vet. Especialistas em Suínos, Goiânia. Embrapa Suínos e Aves, Concórdia, p.2:99-100.

Zanella J.R.C., Morés N., Fernandes L.T., Bassi S.S., Trombetta C. \& Schiochet M.F. 2003b. Ocorrência de circovírus suíno tipo 2 (PCV2) em suínos ou materiais com suspeita clínica de síndrome da refugagem multissistêmica (SRM) enviados para diagnóstico. Anais $11^{\circ} \mathrm{Congr}$. Bras. Vet. Especialistas em Suínos, Goiânia. Embrapa Suínos e Aves, Concórdia, p.295-296. 